\title{
Dioscorea spp. (A Wild Edible Tuber): A Study on Its Ethnopharmacological Potential and Traditional Use by the Local People of Similipal Biosphere Reserve, India
}

OPEN ACCESS

Edited by:

Aiping Lu,

Hong Kong Baptist University,

Hong Kong

Reviewed by:

Funda Nuray Yalcin

Hacettepe University, Turkey

Subhalakshmi Ghosh,

Jadavpur University, India

*Correspondence:

Jayanta Kumar Patra

jkpatra@dongguk.edu

Specialty section:

This article was submitted to

Ethnopharmacology,

a section of the journal

Frontiers in Pharmacology

Received: 18 July 2016 Accepted: 24 January 2017 Published: 14 February 2017

Citation:

Kumar S, Das G, Shin H-S and Patra JK (2017) Dioscorea spp. (A Wild Edible Tuber): A Study on Its Ethnopharmacological Potential and Traditional Use by the Local People of Similipal Biosphere Reserve, India.

Front. Pharmacol. 8:52. doi: 10.3389/fphar.2017.00052

\author{
Sanjeet Kumar ${ }^{1}$, Gitishree Das ${ }^{2}$, Han-Seung Shin ${ }^{3}$ and Jayanta Kumar Patra ${ }^{2 *}$ \\ ${ }^{1}$ School of Life Sciences, Ravenshaw University, Cuttack, India, ${ }^{2}$ Research Institute of Biotechnology and Medical \\ Converged Science, Dongguk University-Seoul, Goyang-si, South Korea, ${ }^{3}$ Department of Food Science and Biotechnology, \\ Dongguk University-Seoul, Goyang-si, South Korea
}

A number of wild crops remain unexplored in this world and among them some have excellent medicinal and nutritional properties. India is a harbor of biodiversity in general and phytodiversity in particular. The plant diversity is distributed from the Western Ghats to Eastern Ghats, along with the North-Eastern region and from the Greater Himalayas to the plain of Ganga. Among these distributed floral regions of the country, the Eastern Ghats are important due to their rich floral diversity. The forests of Odisha form a major part of Eastern Ghats in general and the Similipal Biosphere Reserve (SBR) in particular. The SBR is inhabited by many local communities. The food and medicinal habits of these communities are not fully explored even today. They are dependent on the forests of SBR for their food and medicine. Among their collections from forests, root and tuberous plants play a significant role. The local communities of SBR use about 89 types of tuberous plants for various purposes. Dioscorea is one such tuber, having maximum use among the local of SBR. However, less documentation and no specific reports are available on the food and medicinal values of the species available in this part of the World. Dioscorea species, popularly known as Yam worldwide and as Ban Aalu in Odisha, India, is a prime staple medicinal-food substitute for the majority of rural and local people of the state of India. Of the 13 Dioscorea species available in SBR, 10 species are known to be bitter in taste and unpalatable when taken raw. Since less documentation is available on the Dioscorea species of SBR and their traditional uses, the present study was focused on the ethnobotany, nutritional and pharmacological values of these species along its nutraceutical importance.

Keywords: bioactive compounds, Dioscorea, ethnobotany, food values, ethnopharmacology, Similipal Biosphere Reserve

\section{INTRODUCTION}

Food and health for all are major challenges for the developing countries this century. These challenges need to be addressed robustly. Scientific researchers can find practical solutions by searching for alternate sources of food and medicines. India is rich in phytodiversity, with about 45,000 plant species from the Western Ghats to Eastern Ghats along with the North-Eastern region 
and from the Greater Himalayas to the plain of Ganga. The forests of Odisha form a major part of the Eastern Ghats (Majumadar and Datta, 2015; Pellegrini et al., 2016). The state is also blessed with a biosphere reserve, Similipal Biosphere Reserve (SBR), which covers major part of Eastern Ghats (Figure 1). Besides having large floral biodiversity, SBR is inhabited by many local communities. The food and medicinal habits of these local people are unexplored even today. The forest resources available in this area are most often ill managed due to lack of awareness. In addition, there has been an increasing awareness about the nutritional status of the community, particularly regarding young children and nursing mothers, during recent years (Raju et al., 2015; Ahmed, 2016; Thongam et al., 2016). The Government of India and other organizations are carrying out a number of programs to create awareness; however, malnutrition remains challenge to rural and local communities of India. The condition is still worse in a state like Odisha in general and among the local communities of SBR in particular.

Appropriate nourishment needs to be pursued at household level, particularly in remote areas like SBR. The solution to these burning problems can be achieved through measured use of available natural resources. To fulfill their needs, people try to get their nutritional and medicinal requirements through nonconventional means, by consuming various wild plants and their parts (Singh and Arora, 1978). Such nonconventional sources are directly related to biodiversity. Nature provides numerous wild edible-medicinal products, such as leaves, flowers, fruits, nuts, berries, stems, roots, and tubers (Chandrasekara and Kumar, 2016; Geng et al., 2016; Hailu and Addis, 2016; Keservani et al., 2016). Among these, roots and tubers come under the minor wild crops, having very less scientific documentation, although they play important roles to fight against food scarcity. As wild tuber crops available in SBR, Discorea sp. (Ban aalu) species play a prime role in providing food and medicinal requirements for the local communities (Kumar et al., 2012, 2013a,b).

There are about 13 types of Dioscorea species found in SBR. The most common Dioscorea species are D. bulbifera L. (Pita aalu), D. pentaphylla L. (Panja Sanga), D. hispida Dennst. (Banya aalu), D. alata L. (Khamba aalu), D. oppositifolia L. (Paani aalu), D. pubera Blume (Kukai Sanga) etc. Ten species are known to be bitter in taste or unpalatable when taken raw. The rural and local people who use them as food supplements make them edible by different traditional practices. While investigating traditional food systems and palatability of Dioscorea species available in SBR, it was observed that tubers are mostly soaked overnight in water or left overnight in stream and subjected to successive boiling to remove the bitterness (Bhandari and Kawabata, 2005; Kumar et al., 2012; Misra et al., 2013). Dioscorea species with nutritive and antioxidant content not only enrich the diet of the local rural and local people but also make them ethnomedicinally important (Son et al., 2014; Chandrasekara and Kumar, 2016; Cui et al., 2016; Liu et al., 2016; Zhang et al., 2016). Tubers of different species of Dioscorea are used for curing various diseases and ailments in different formulations. Most of the tubers of Dioscorea examined in the present study are used for birth control and skin infections. Tubers and vegetative parts of these species are used either in single or in multiple formulations.
A harmonious blend of indigenous knowledge is therefore essential to document and promote proper utilization of such resources available in the state. In this context, the present study found some unique and unreported ethnobotanical claims of Dioscorea species available in SBR. Knowledge of local practitioners and millions of aboriginals from generation to generation flows into the mainstream, which has emerged as a traditional therapeutic system. However, the modern scientific mind cannot accept such local knowledge unless it is experimentally substantiated. The curative properties of medicinal and aromatic plants are due to the presence of certain bioactive compounds in them (Arunachalam et al., 2015; Atansov et al., 2015; Yamani et al., 2016). Through literature survey, the bioactive compounds present in the vegetative parts of some Dioscorea species were noted and concluded. The bioactive compounds presents in most of the Dioscorea species are in the phenolic group of compounds (Liu et al., 2011; Ghosh et al., 2012; Raju and Rao, 2012; Kumar et al., 2013a; Schulte et al., 2013; Saxena and Raja, 2014; Woo et al., 2014; Yang et al., 2014; Dzialo et al., 2016; Price et al., 2016; Van, 2016). Keeping all the properties of Dioscorea species available in SBR and utilized by the local community of SBR, an attempt has been made here to document the ethnobotanical and ethnopharmacological values of Dioscorea species used by the local communities of SBR, Odisha, India which would be helpful for researchers for utilization of this plant species in pharmaceutical applications and drug discovery.

\section{SIMILIPAL BIOSPHERE RESERVE}

Similipal in Odisha state of India was designated as a biosphere reserve in June 1994, as the representative ecosystem under the Eastern Ghats. The SBR (Figure 1) has a unique assemblage of a number of ecosystems, such as mountains, forests, grasslands, and wetlands, which congregate into a contiguous patch with a range of diverse vegetation types. Its rich flora and fauna with many indicator species make the region a unique base for ecological studies. The biosphere reserve has varied topography and geologic formations, and rich biodiversity. It is also the habitat of many aboriginals (Das and Das, 2008).

The SBR is called the "Himalayas of Odisha" as it controls the climatic regime of parts of Odisha, Jharkhand, West Bengal, and Eastern India (Saxena and Brahmam, 1989). It harbors the largest tropical peninsular Sal zone forming a biological link between Northern and Southern India. The SBR is located in central part of Mayurbhanj district in Odisha state of India, close to the interstate boundary with West Bengal state in the North-East direction and Jharkhand state in the NorthWest (Misra, 1997; Girach et al., 1999; Behera, 2006; Reddy et al., 2007; Thatoi et al., 2008; Rout et al., 2009). It extends between $21^{\circ} 10^{\prime}$ to $22^{\circ} 12^{\prime} \mathrm{N}$ latitude and $85^{\circ} 58^{\prime}$ to $86^{\circ} 42^{\prime}$ $\mathrm{E}$ longitude, ranging between 300 and $1180 \mathrm{~m}$ above sea level. SBR is a firm mass of natural forest spread over a total area of $5569 \mathrm{~km}^{2}$ with core $\left(845 \mathrm{~km}^{2}\right)$ and buffer zones $\left(2,129 \mathrm{~km}^{2}\right)$ composed of 16 forest ranges surrounded by a transitional zone $\left(5,569 \mathrm{Km}^{2}\right)$. The average elevation is 559.31 meters (Mohanta 


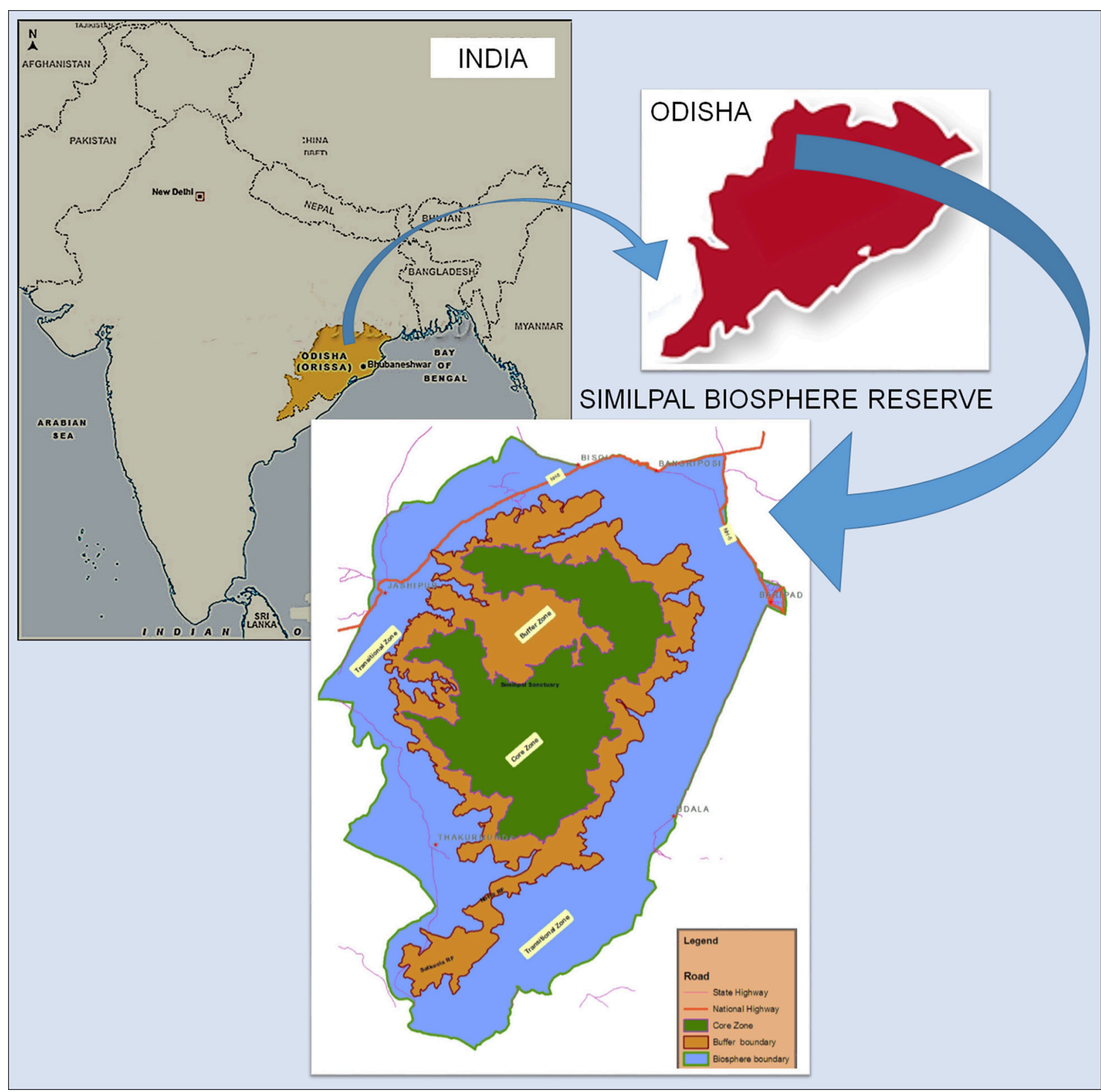

FIGURE 1 | Geographical location of the study area (Similipal Biosphere Reserve).

et al., 2006; Misra et al., 2011; Panda et al., 2011). The highest point in this group of hills is the Meghasani Hill (literally meaning The Seat of Clouds), which rises to about 1166 meters above sea level. Durdurchampa (1009 meters) and Chahala (775 meters) are the other important hills of the area (Saxena and Brahmam, 1989). Thus, SBR has idiosyncratic biodiversity harboring number of endemic, threatened, rare, medicinal, and economically important plants. Recent reports indicate, SBR has around 1254 species of vascular plants, representing $46 \%$ of the flora of Odisha and $7 \%$ that of India, including about 94 species of orchids, and about 52 species of rare/ endangered plants (Yoganarasimhan and Dutta, 1972; Swain and Nanda, 1997; Misra et al., 2003, 2011, 2013; Reddy et al., 2007; Rout and Thatoi, 2009; Mishra et al., 2011; Kumar et al., 2012).

\section{LOCAL COMMUNITIES OF SIMILIPAL BIOSPHERE RESERVE AND THEIR TRADITIONAL USE OF DIOSCOREA SPECIES}

The extensive and densely forested hilly tracts of SBR are the home of many local communities, such as Bathudi, Bhumija, 
TABLE 1 | Ethnobotanical values of common Dioscorea species of SBR, India.

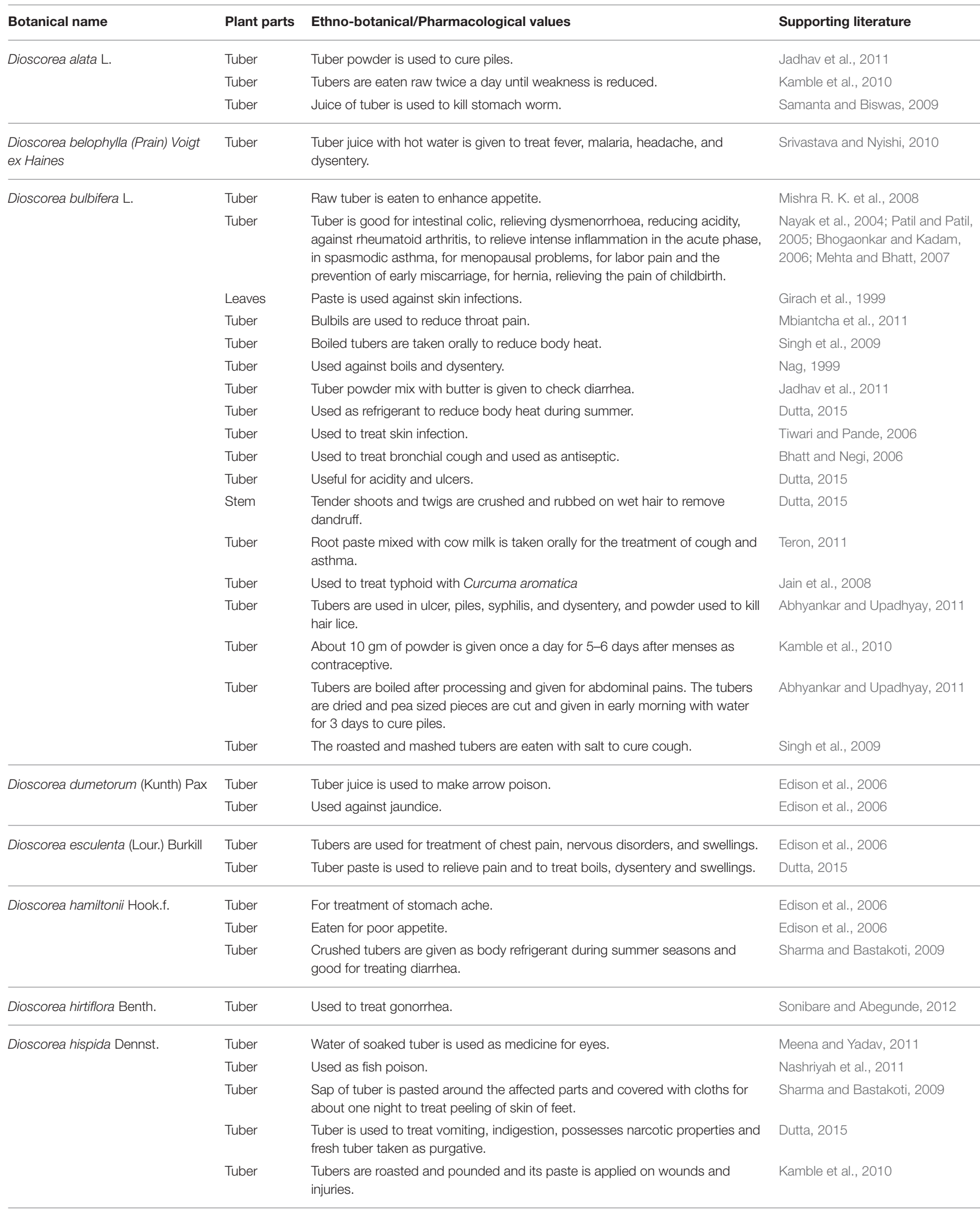


TABLE 1 | Continued

\begin{tabular}{|c|c|c|c|}
\hline Botanical name & Plant parts & Ethno-botanical/Pharmacological values & Supporting literature \\
\hline Dioscorea kamoonensis Kunth & Tuber & Tubers are used in the treatment of arthritis and rheumatism. & Edison et al., 2006 \\
\hline \multirow[t]{5}{*}{ Dioscorea oppositifolia L. } & Tuber & $\begin{array}{l}\text { Tuber is boiled with } D \text {. uniflorus and is given to women once a day for nearly a } \\
\text { month after delivery to revive their strength. }\end{array}$ & Mishra S. et al., 2008 \\
\hline & Tuber & $\begin{array}{l}\text { Oral administration of tuber powder mixed with honey is used for increasing } \\
\text { sperm. }\end{array}$ & Sharma and Bastakoti, 2009 \\
\hline & Leaf & Leaf paste is used as antiseptic for ulcers. & Sheikh et al., 2013 \\
\hline & Tuber & Powered root mixed with cow urine is applied on scorpion bite. & Nashriyah et al., 2011 \\
\hline & Tuber & $\begin{array}{l}\text { Leaves are mixed with leaves of clematis and 2-3 drops of juice put in the } \\
\text { nose of affected person to get relief after sneezing in fits and epilepsy. }\end{array}$ & Kamble et al., 2010 \\
\hline \multirow[t]{6}{*}{ Dioscorea pentaphylla L. } & Tuber & $\begin{array}{l}\text { Tubers are applied on swelling of joints and used as tonic to improve body } \\
\text { immunity. }\end{array}$ & Edison et al., 2006 \\
\hline & Tuber & Used for stomach pain. & Choudhary et al., 2008 \\
\hline & Tuber & $\begin{array}{l}\text { Crushed mass of tuber is given to cattle when they become sick by eating } \\
\text { green leaves of maize. }\end{array}$ & Sharma and Bastakoti, 2009 \\
\hline & Tuber & $\begin{array}{l}\text { Tuber is used as tonic and also used to cure stomach troubles and rheumatic } \\
\text { swellings. }\end{array}$ & Dutta, 2015 \\
\hline & Tuber & Inflorescence is used as vegetables for body weakness. & Kamble et al., 2010 \\
\hline & Tuber & Tubers are useful to allay pain and swelling. & \\
\hline Dioscorea pubera Blume & Bulbils & Bulbils are cooked and taken to cure colic pain. & Sheikh et al., 2013 \\
\hline \multirow[t]{2}{*}{ Dioscorea wallichii Hook.f. } & Tuber & Roasted and eaten for flatulence. & Dutta, 2015 \\
\hline & Tuber & Used in stomach pain. & Rout and Panda, 2010 \\
\hline Dioscorea spinosa Burm. & Tuber & Tubers are edible in the district Mayurbhanj of Odisha, India. & Behera, 2006 \\
\hline
\end{tabular}

Gonda, Ho, Kolha, Mahali, Munda, Pauri Bhuiyan, Santhal, and Saunti, including two primitive groups, Hill-Kharia and Mankirdia (Saxena and Brahmam, 1989; Pandey et al., 2000; Pandey and Rout, 2003; Mohanta et al., 2006; Mishra, 2010; Kumar et al., 2012; Misra et al., 2013; Pedi et al., 2013; Sahoo, 2013). There are around 61 villages inside the core and buffer zone and about 1200 villages in the transitional zone, having a total population of about $4,50,000$, out of which the scheduled tribes constitute $73.44 \%$ of the total population of Similipal (Mishra, 2010; Mishra et al., 2011; Upadhyay et al., 2012). These poor local peoples practice primitive culture, traditions, and rituals, and have no or very few acquired skills. Their main occupation is food gathering, hunting, collection of forest products, and traditional farming or agriculture. In the present study, the Ho, Bathudi, Mankirdia, Kolho, Munda, and Santhal were selected for detailed study on their traditional knowledge on Dioscorea species.

The "Ho" is a Kolarian ethnic group belonging to the same stock of Munda and Kol. They mainly cultivate rice, maize, and millets along with seasonal vegetables. They also collect different types of wild plants from the forest and store them (Ota et al., 2013). They usually collect tubers and rhizome, including starchy tubers of Dioscorea species. They use tubers as food and medicine (Tables 1, 2). They are inhibiting from collecting D. pubera Blume (Figures 2.3, 2.5) during rainy seasons. Mankirdia is a primitive tribe that constitutes a semi-nomadic section of the Birhor tribe (Ota, 2007; Dash, 2011). They are primarily a hunting and food gathering community (Ota and Mohanty, 2008). The present study observed that they wander from Similipal to Hazaribagh National Park (Jharkhand) and return after a year to Similipal again (Source: Token Mankirdia, interviewed near the Kalikaparsad gate, transitional zone of SBR). During their movement in forest, they collect various types of medicinal plants to cure common diseases. They collect tuber of D. bulbifera L. (Figure 2.2) and D. pentaphylla L. (Figure 2.1) for curing skin infections, and abdominal pain, and for birth control (Kumar et al., 2012; Misra et al., 2013). They also collect tubers during early winter and store them for consuming in the summer and rainy seasons. The Hill-Kharia, locally known as "Pahari Kharia" is a highland local group (Ota et al., 2008). They are expert in collection of honey, resin, and arrowroot. They are primarily a forager community in the SBR. They do major seasonal collection along with agricultural labor in the agricultural season (Ota and Sahoo, 2013). During the rainy season, most of the Hill-Kharia face rice scarcity, and they principally depend on other food stuffs, like maize, edible roots, and tubers of Dioscorea species and corns. The Santhals, one of the common local communities of India, mainly inhabit in the districts of Mayurbhanj, Keonjhar, and Balasore in the state of Odisha, India. They collect minor forest products like tubers, roots, fruits, green leaves, honey, mahua flowers, etc., that sustain them for 3-4 months in a year (Ota and Patnaik, 2014). Bathudi is also a very common local community in SBR. They are simple and shy in nature. They are excellent at agriculture and gathering forest products and medicinal plants. A detailed study on Dioscorea species is presented below. 
TABLE 2 | Common medicinal uses of Dioscorea species available in SBR, India.

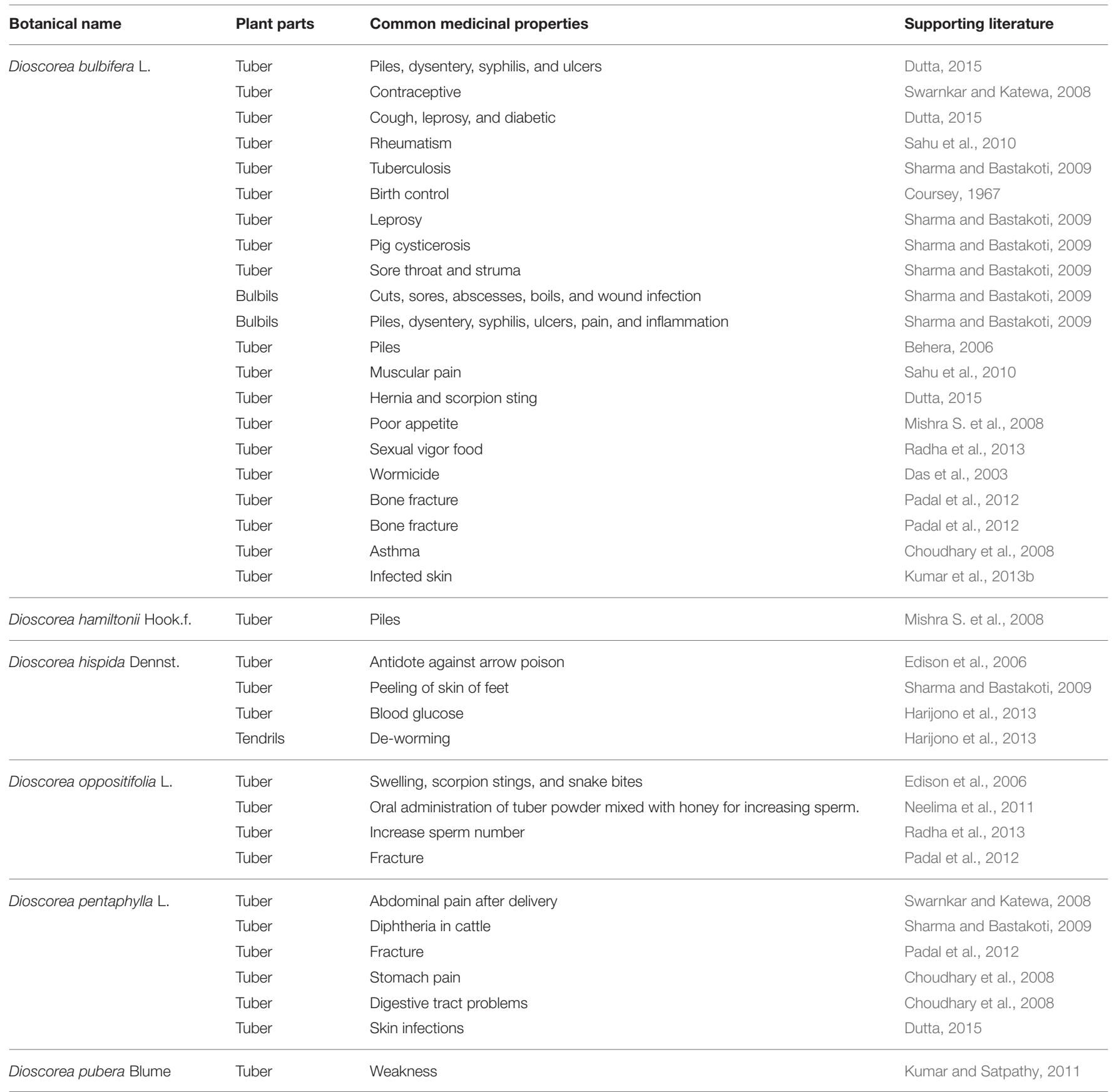

\section{DIOSCOREA SPECIES: THE WILD TUBER CROP}

\section{Origin, Habitat, and Distribution}

The genus Dioscorea belongs to the family Dioscoreaceae, the most prominent within the order Dioscoreales (Burkill, 1960; Ayensu and Coursey, 1972; Dansi et al., 1999; Tamiru et al., 2008; APG III, 2009). The family is believed to be one among the earliest angiosperms, and it probably originated in Southeast Asia (Coursey, 1967). The various Dioscorea species apparently followed a divergent evolution in three continents separated by the formation of the Atlantic Ocean and desiccation of the Middle East (Hahn, 1995). As a result, this major species occur in three isolated centers: West Africa, Southeast Asia, and Tropical America (Alexander and Coursey, 1969). These centers are also considered areas for independent yam domestication, and represent considerable diversity (Asiedu et al., 1997). 


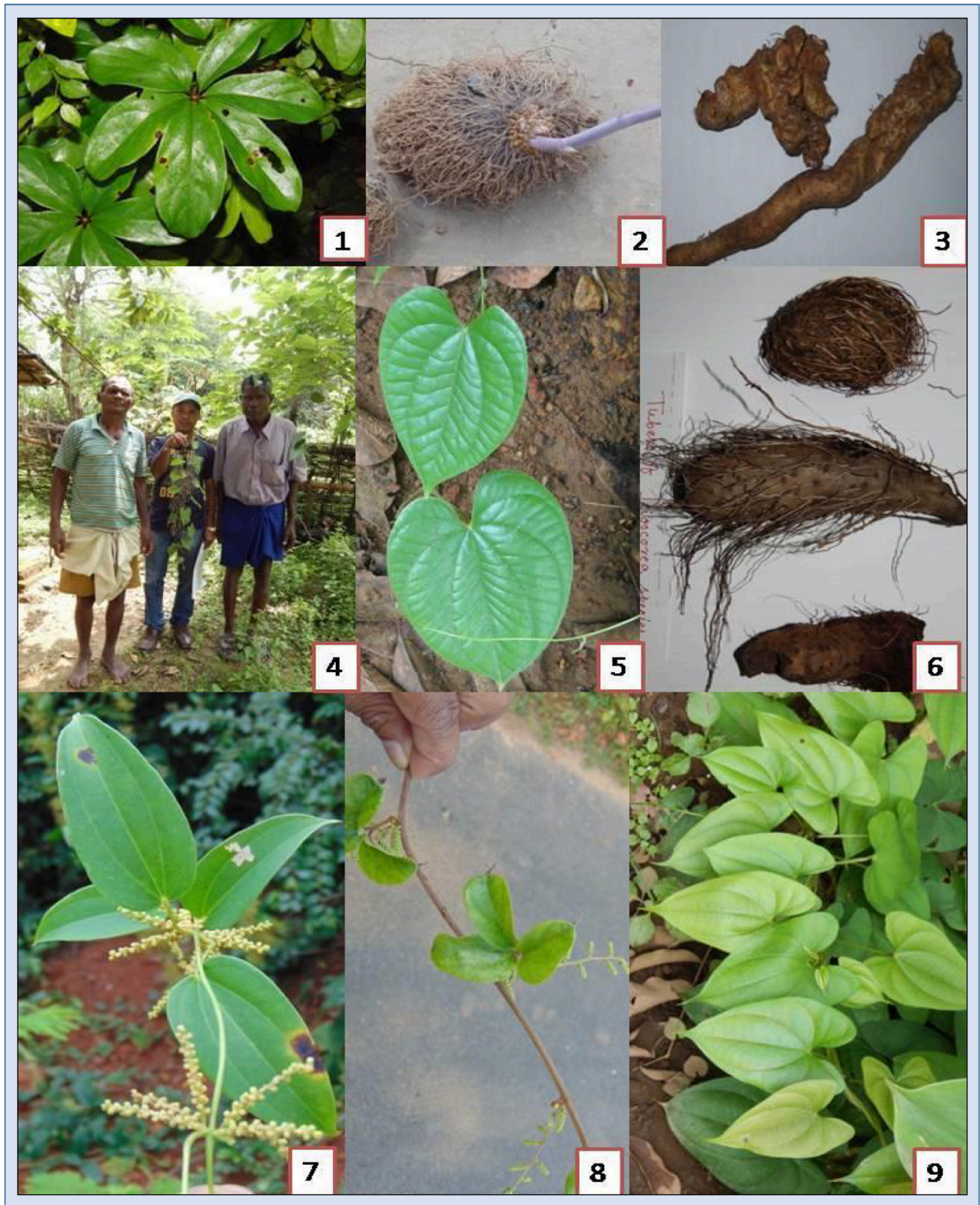

FIGURE 2 | Some common Dioscorea species of Similipal Biosphere Reserve. (1) $D$. pentaphylla leaves, (2) Tuber of $D$. bulbifera, (3) Tubers of $D$. puber,

(4) D. bulbifera with tribal communities of SBR, (5) D. puber leaves, (6) Tuber of different Dioscorea spp., (7) Flowers of D. oppositifolia, (8) Flowers of $D$. hispida, and (9) D. alata

Among the selected Dioscorea species, the most economically important species, D. alata L., originated in Southeast Asiamore specifically, in Tropical Myanmar and Thailand (Orkwor et al., 1998; Tamiru, 2006), and currently it is the most diversified and extensively distributed species. It is distributed throughout the Tropics, Southeast Asia, Papua New Guinea, Indonesia, Malaysia, Philippines, South Pacific Islands, Vanuatu, West Africa, Brazil, the Caribbean, South America, Central 
America, Florida, Escambia, Gadsden, Leon, Levy, and Charlotte (Gooding, 1960; Coursey, 1967; Lebot et al., 1998, 2006; Mignouna and Dansi, 2003; Scarcelli et al., 2006; Ahmad and Uroj, 2008; Hgaza et al., 2011). The other most popular among studied Dioscorea species is D. bulbifera L. The native range of this species is vast, and includes much of Asia, tropical Africa, and Northern Australia (Coursey, 1967; Terauchi et al., 1991; Onwueme and Charles, 1994).

Another species, D. bulbifera L. (Figure 2.4) is native to South Asia and distributed in Central and South America, Africa, Australia, Louisiana, Texas, Hawaii, Puerto Rico, Polynesia, Florida, and West Africa. (Coursey, 1967; Schultz, 1993; Langland and Burks, 1998) while D. hispida Dennst. (Figure 2.8) is distributed in Tropical and Sub-tropical regions, Philippines, China, Taiwan, Malaya, New Guinea, Malaysia, Fujian, Bhutan, Indonesia, Bangladesh, Sikkim, Thailand, Cambodia, Laos, Myanmar, Vietnam, and Africa (Sharma and Bastakoti, 2009; Nashriyah et al., 2011). D. pubera Blume is native to the IndoChina region (Asiedu et al., 1997) and D. pubera Blume is distributed throughout the temperate, tropical Americas, China, wet regions of Himalayas, Central Nepal, Western Malaysia, and Bhutan (Coursey, 1967).

The other most important highly yielding (tuber size) species is D. pentaphylla L. and it is native to Tropical Asia and Eastern Polynesia and is distributed in South-Eastern Asia, Tropical Asia, Kauai, Molokai, Hawaii, Tahati, Savii, North America, and Florida (Ayensu and Coursey, 1972). These species are distributed in most parts of the world and throughout the country of India. In India, the populations of these species are rich in Eastern and Western Ghats. The distribution of Dioscorea species selected for the present study is given below.

In India, the most common Dioscorea species is D. alata L. (Khambha Aalu) distributed throughout the country, and rich in Odisha. In SBR the species is dominating in peripheral areas such as Jashipur, Karanjia, Hatibadi, Manda, and Bisoi (Kumar et al., 2012) and D. pubera Blume (Kukai Sanga) is distributed mainly in areas like the Himalayas, Sikkim, Assam, Northern Bengal, Western Ghats, Jharkhand, Bihar, Upper Gangetic Plain, Kerela, Wayanad, Udupi, and Andhra Pradesh of the country. In SBR, its population is rich in Kasipani, Kolha, Gurguria, and Ghatkumari. It is very frequent in Bangriposi Ghati and Gurguria forest range (Saxena and Brahmam, 1995; Kumar et al., 2012; Misra et al., 2013).

The second richest Dioscorea species after D. alata L. is the D. bulbifera L. (Pita Aalu). It is distributed mainly in the forest patches of Eastern Ghats to the lower Himalayas in the Indian subcontinent. In SBR, It is widely distributed in Bangriposi Ghati, Gurguria, Sanuski, Nawana, Bakua, Kukurbhuka, Kalika Parsad and surrounding areas (Kumar et al., 2012) while D. pentaphylla L. (Panja Sanga) is distributed in Deccan, Western Himalayas, Rajasthan, Nasik, and Odisha states of the country. In SBR, it is rich in the hill slopes of Gurguria, Sanuski, Bangriposi, Ghatkumari, Astakumar, Nawana, and Joranda (Kumar et al., 2012). D. hispida Dennst. (Banya Aalu) is distributed throughout the mountainous areas of the country. It is very common in Odisha, Jharkhand, Andhra Pradesh and Telangana states. In $\mathrm{SBR}$, it is distributed in the shady buffer and peripheral areas and along the streams, particularly in Ghatkumari and Padampur (Kumar et al., 2012). The above all information show the rich distribution of these species not only in the India but throughout the world.

\section{BOTANY OF DIOSCOREA SP.}

The word "Yam" is applied to members of the genus Dioscorea belonging to the family Dioscoreaceae in the order Dioscoreales (Alexander and Coursey, 1969). Wild species are either annuals or semi-perennials or perennials. Cultivated species are annuals. Generally, the female plants are less in number than the male plants. Most Dioscorea species have simple, cordate, or acuminate leaves borne on long petiole, but in some species, they are lobed or palmate with pointed tips. They are climbers and climb by twining. The direction of twining of the vine (i.e., anti-clock wise or clock wise) is a characteristic peculiar to the particular sections within the genus Dioscorea. The wings present in some species, such as D. alata L. (Figure 2.9), support the twining habit. The flowers are basically dioecious, with male and female flowers borne separately or on separate plants. The male or female flowers are borne on axillary spikes in the leaf axils. The male flowers are sessile, glabrous, and spherical and are borne axially or terminally. These flowers consist of calyx of three sepals and corolla of three petals, arranged regularly and almost similar in size and appearance, with three or six stamens (Onwueme, 1978). Fruits are mostly capsules. The seed in each capsule is small and has wings that vary in shape in different species (Onwueme, 1978). The seeds are flat and light, and the wings help in wind dispersion. Some species, such as D. alata L., D. bulbifera L., D. pentaphylla L., D. pubera Blume, have bulbils in the axils. Bulbils are specifically adapted for vegetative propagation (Coursey, 1967). They are very smaller than the underground tubers. Short day length generally accelerates formation of bulbils. Dioscorea possess shallow fibrous root systems, normally un-branched and concentrated within the top layer of the soil, and very few actually penetrate up to $1 \mathrm{~m}$ depth (Onwueme, 1978). The tuber is the storage organ, which forms a new tuber and shrivels away simultaneously when the re-growth is induced. When the organ lacks the typical characteristics of a modified stem structure, the tuber has no preformed buds or terminal bud at the distal end (Hahn et al., 1987).

\section{ETHNOBOTANICAL VALUES OF DIOSCOREA SP.}

Dioscorea have sound ethnobotanical values throughout the Tropics. There are numerous reports available on local claims on Dioscorea species worldwide. In some forest areas of Southern Thailand, which are situated in the Tropical rain forest zone of Southeast Asia, local people use Dioscorea species to treat warts (Maneenoon et al., 2008). The boiled tubers of D. membranacea Pierre ex Prain \& Burkill are used to treat asthma and fever (Maneenoon et al., 2008). The mucilage from the tubers of D. piscatorum Prain \& Burkill is used to poison fish is used by the native people of Malaysia as a piscicide (Burkill, 1951, 
TABLE 3 | Nutrient content of Yam in comparison with other crops.

\begin{tabular}{|c|c|c|c|c|c|c|c|}
\hline & & & Crops & & & & \\
\hline Staple & Maize / Corn & Rice & Wheat & Potato & Cassava & Soybean (Green) & Yam \\
\hline \multicolumn{8}{|c|}{ COMPONENT (PER 100G PORTION) } \\
\hline Water (g) & 10 & 12 & 13 & 79 & 60 & 68 & 70 \\
\hline Protein (g) & 9.4 & 7.1 & 12.6 & 2.0 & 1.4 & 13.0 & 1.5 \\
\hline Fat $(g)$ & 4.74 & 0.66 & 1.54 & 0.09 & 0.28 & 6.8 & 0.17 \\
\hline Carbohydrates (g) & 74 & 80 & 71 & 17 & 38 & 11 & 28 \\
\hline Fiber (g) & 7.3 & 1.3 & 12.2 & 2.2 & 1.8 & 4.2 & 4.1 \\
\hline Sugar (g) & 0.64 & 0.12 & 0.41 & 0.78 & 1.7 & 0 & 0.5 \\
\hline
\end{tabular}

1960). D. prazeri Prain \& Burkill is used as soap and shampoo to kill lice in India (Maneenoon et al., 2008). Dioscorea is used in curing gastritis among Yoruba local groups of Cuba (Kadiri et al., 2014). Tubers of D. hamiltonii Hook.f. are used as body refrigerant during summer and are also used to treat diarrhea (Dutta, 2015). D. bulbifera L. is used against tuberculosis and raw tuber of $D$. pentaphylla L. against diphtheria in cattle (Sharma and Bastakoti, 2009). Tubers of D. oppositifolia L. (Figure 2.7) are used in the treatment of swellings, scorpion stings, and snake bites (Dutta, 2015). Juice of D. wallichii Hook.f. is used in the treatment of Jaundice. D. hispida Dennst. (Figure 2.6) is used as an antidote to arrow poison (Sinha and Lakra, 2005; Edison et al., 2006; Mishra S. et al., 2008; Swarnkar and Katewa, 2008; Sahu et al., 2010). Details of ethnobotanical values of different species of Dioscorea are listed in Table 1. Besides the traditional therapeutic values, many researchers reported other pharmacological/ common uses of different Dioscorea species.

\section{FOOD VALUES OF DIOSCOREA SP.}

Since the adoption of the convention on biodiversity in 1992, there has been a general agreement on the importance of biodiversity, especially the diversity of wild and cultivated plants, to fill the need of the world population for food (FAO, 1998). In developing countries like India, people do not get enough food to meet their daily requirement, and most often the diet is deficient in one or more micronutrients (FAO, 1994). India faced a series of famines and major food shortages before 1940s. National food grain production was merely 50.82 million tons during 19501951, but has risen to 264.38 million tons in 2012-2013 (FAO, 1994). Edible roots and tubers not only enrich the diet due to the presence of starch and energy supplemented metabolites in them, but also possess medicinal properties due to the presence of diverse secondary metabolites. The tuber crop under study here, Dioscorea, is superior to many others as an important medicofood used by about 300 million people throughout the world (Arnau et al., 2010). In fact, they are one of the principal sources of energy food for many people in the Tropics (Nayaboga et al., 2014). As per source of dietary nutrients, Dioscorea species rank as the world's fourth most important root and tuber crops after potatoes, cassava, and sweet potatoes (Lev and Shriver, 1998). Many of the tubers of Dioscorea are bitter in taste, and local people use traditional skills to remove bitterness. Aboriginals also use their tubers as snacks, and in roasted, powdered, and other forms (Kumar et al., 2012; Misra et al., 2013). The same processes are also followed in various parts of India, including the Himalayan regions and North-Eastern part of India (Sheikh et al., 2013), Orissa (Sinha and Lakra, 2005; Kumar and Satpathy, 2011; Kumar et al., 2012; Misra et al., 2013), Tamil Nadu (Rajyalakshmi and Geervani, 1994; Shajeela et al., 2011), and among Palliyar and Kanikkar tribes (Shanthakumari et al., 2008; Arinathan et al., 2009) living in South-Eastern slopes of Western Ghats (Padmaja et al., 2001). They are also used by the local of Kumaon and Garhwal hills of India (Pramila et al., 1991). The nutrient content of the Yam has been compared with several other crops (Table 3; Wanasundera and Ravindran, 1994).

Out of about 600 species, only 10 species of Dioscorea are cultivated throughout the world. In India, about 26 Dioscorea species are reported, and of them 13 are reported in SBR, Odisha (Kumar et al., 2012). Out of these 13 species, only one, D. alata L., is cultivated in this region, and the remaining species mostly grow wild in this zone. Tubers of 12 wild Dioscorea species available in Odisha have sound nutritional values, but have low palatability due to their bitterness (Kumar et al., 2012). Dioscorea the starchy edible tuber is of ample economic and nutritional importance in the Tropical and Sub-tropical regions of the world (Sharma and Bastakoti, 2009). In fact, the tubers are rich sources of food and energy (Table 3). The world's estimated yam production in 2010 was 48.7 million tons (Abasi et al., 2013). They have been reported to be good sources of essential dietary nutrients (Wanasundera and Ravindran, 1994).

\section{BITTERNESS AND DIOSCOREA SP.}

In spite of their nutritional importance, they possess some antinutritional factors and secondary metabolites, which make them bitter in taste and reduce the palatability. The major toxic content is dioscorine, an alkaloid present in most of the species of Dioscorea (Lu et al., 2012). Dioscorine triggers fatal paralysis of the nervous system (Reddy, 2015). Similarly, histamine was reported to be the principal allergen present, causing mild inflammation and itching (Shim and Oh, 2008). Some other compounds found in Dioscorea are furanoid-norditerpene, saponin, oxalate, tannin, and phytic acid. The primary bitter 
TABLE 4 | Common bioactive compounds present in Dioscorea species of SBR, India.

\begin{tabular}{|c|c|c|c|}
\hline Compounds & Uses & Species & Source(s) \\
\hline Diosgenin & Synthesis of steroidal drugs & Dioscorea deltoidea Wall. ex Griseb. & Asha and Nair, 2005 \\
\hline Sapogenin & Anti-inflammatory effect & Dioscorea spp. & Martin, 1969 \\
\hline Saponin & Skin infections & Dioscorea spp. & Nayaboga et al., 2014 \\
\hline Cyanidin & Exhibit trypsin inhibitors & Dioscorea spp. & Hou et al., 2000 \\
\hline Flavonoids & Skin infections & Dioscorea belophylla (Prain) Voigt ex Haines & Poornima and Ravishankar, 2007 \\
\hline Allantoin & Detoxification of ammonia & Dioscorea spp. & Fujihara and Yamaguchi, 1978 \\
\hline Dioscorine & Birth control & Dioscorea bulbifera L. & Adetoun and Ikotun, 1989 \\
\hline Ohenolic compounds & Skin infections & Dioscorea pentaphylla L. & Kumar and Jena, 2014 \\
\hline
\end{tabular}

components present in the tubers of $D$. bulbifera $\mathrm{L}$. have been identified by several researchers as the "furanoid norditerpenes" (diosbulbins A and B) (Martin, 1974; Webster et al., 1984; Bhandari and Kawabata, 2005). Therefore, various techniques are implemented to reduce or to eliminate the bitterness by the people. Most common techniques used to reduce the bitterness includes boiling/steaming and/or baking over coals after either cleaning (bulbils) or cleaning and peeling (tubers) (Bhandari and Kawabata, 2005). Martin (1974) documented that the tubers of several toxic varieties of $D$. bulbifera $\mathrm{L}$. are made palatable by the above said techniques and are used as a source of food during the extreme conditions such as drought and or famine. In some places, the detoxification is done with lime or sand and then slow-roasting or repeated boiling with wood ashes followed by steeping sliced pieces in running water (Martin, 1974; Webster et al., 1984).

\section{PHARMACOLOGICAL POTENTIAL OF DIOSCOREA SP.}

Studies reveal that the tubers of Dioscorea species possess high amounts of polyphenolic compounds (Liu et al., 2011). Several researchers have reported the pharmacological importance of Dioscorea species (Kumar and Jena, 2014). Dioscorea species have been reported to have anti-oxidative, anti-fungal, antimutagenic, hypoglycaemic, and immunomodulary effects (Son et al., 2007). They are also used as important ingredients of dietary supplements and in cosmetics and pharmaceutical industries (Black et al., 2007). Tubers and other parts of Dioscorea possess different types of phenolic compounds, which might be responsible for the antimicrobial activities (Sara et al., 2010). Aderiye et al. (1996) reported the antifungal activity of D. alata L. peel extracts.

In the year 2003, Seetharam et al. (2003) documented the antimicrobial activity of D. bulbifera L. (bulbil) against Klebsiella pneumoniae, Escherichia coli, Proteus vulgaris, Staphylococcus aureus, Aspergillus niger, Aspergillus flavus, Aspergillus fumigatus, and Rhizopus nigricans. Many authors have reported the antimicrobial potential of different species of Dioscorea sp. in different studies such as antibacterial activities of D. zingiberensis C.H. Wright by Xu et al. (2008); antimicrobial activity of D. hamiltonii Hook.f. tubers with Azadirachta indica stem by
Kaladhar et al. (2010); the antibacterial activity of D. pentaphylla L. against $S$. aureus, $P$. aeruginosa, and $K$. pneumoniae, and anti-fungal activity against Trichophyton rubrum, Microsporum gypseum, Trichophyton tonsurans, Microsporum audouini, and Candida albicans found in the mid-Western Ghats by Prakash and Hosetti (2010). The antibacterial activity of D. villosa L. tubers against $S$. dysenteriae, E. coli, V. cholerae, K. pneumoniae, $P$. aeruginosa, and $S$. aureus was also reported (Roy et al., 2012).

The silver nano-particles synthesized from Dioscorea tuber extracts were found to possess potent synergistic antibacterial activity with combination of antibiotics (Ghosh et al., 2012). The folkloric uses of the studied plants and provided evidence that tuber extracts of D. dumetorum (Kunth) Pax and D. hirtiflora Benth. might indeed be potential sources of natural antioxidant and antimicrobial agents in Nigeria as reported by Sonibare and Abegunde (2012). Chandra et al. (2013) documented the antimicrobial activity of all extracts of $D$. deltoidea Wall. ex Griseb. against ten (gram negative and gram positive) bacteria and three fungal strains. Begum and Anbazhakan (2013) described the antimicrobial activity of tuber mucilage extracted from D. esculenta (Lour.) Burkill by in vitro-well diffusion assay against E. coli, K. pneumoniae, P. aeruginosa, S. aureus, and Streptococcus pyogenes. The extracts showed significant antibacterial activity against $E$. coli, $P$. aeruginosa, and $S$. aureus, while no activity was observed by the extracts against K. pneumoniae and S. pyogenes.

Many studies have also shown the anti-oxidant potentials of these tuber crops. Araghiniknam et al. (1996) observed the antioxidant activity of Dioscorea species. Hou et al. (2001) documented the antioxidant activity of dioscorin of yam (D. batatas Decne.) tubers. Hou et al. (2002) also reported the antioxidant activity of yam (D. batatas Decne.) tuber mucilage. In the year 2004, Dong et al. (2004) testified steroidal saponins from D. panthaica Prain \& Burkill and their cytotoxic activity from an ethanol extract of the rhizomes of $D$. panthaica Prain \& Burkill and in the same year, Yu et al. (2004) have also stated the anticancer effects of various fractions extracted from D. bulbifera L. on mice bearing HepA. Further, Chang et al. (2004) have described that Chinese yam (D. alata L.) had antioxidative effects in hyperhomocysteinemia rats. Similarly, Liu et al. (2006) documented the antioxidant activities of selected Dioscorea species using DPPH radical, hydroxyl 


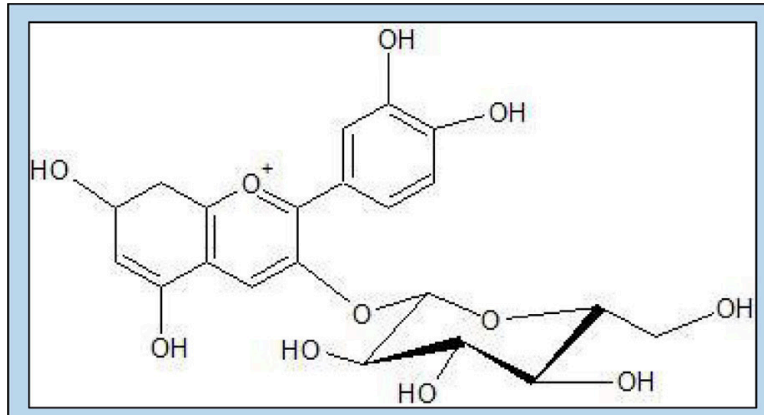

Chrysanthemin

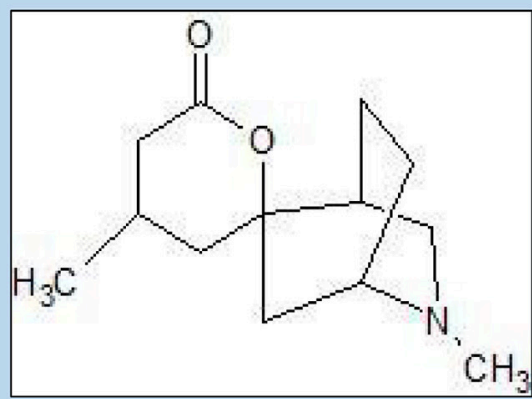

Dihydrodioscorine

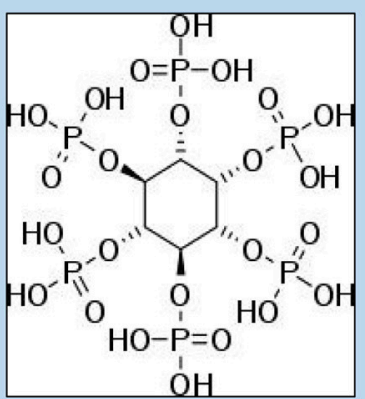

Phytic acid

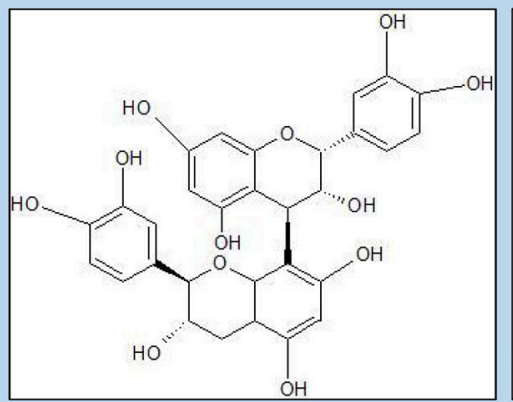

Procyanidin B1

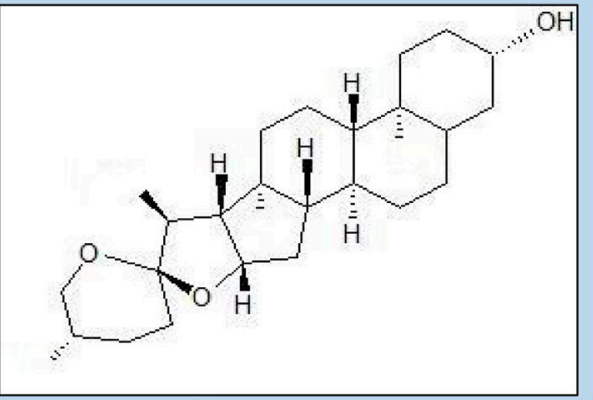

Sapogenin

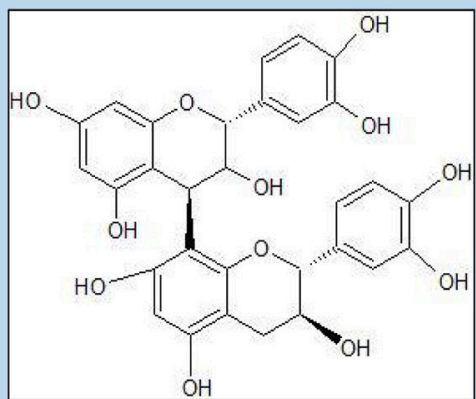

Procyanidin B2<smiles>O=[N+]([O-])c1cc([N+](=O)[O-])c(O)c([N+](=O)[O-])c1</smiles>

Discoeine

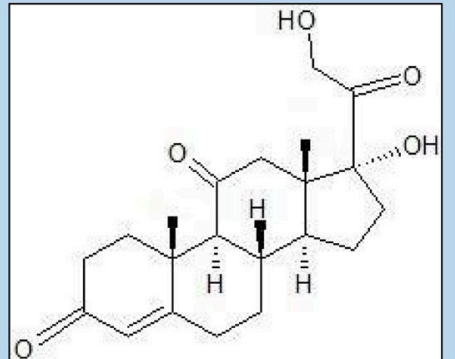

Cortisone

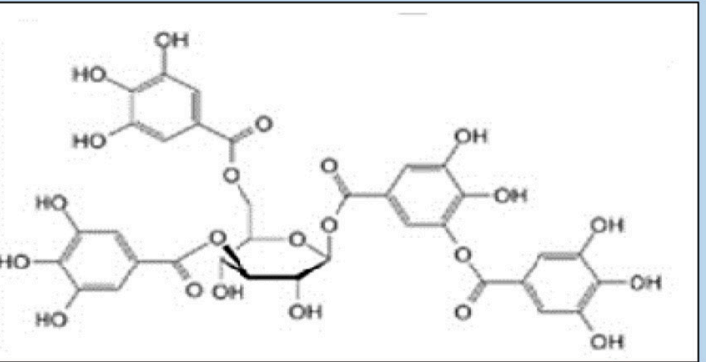

Tannin

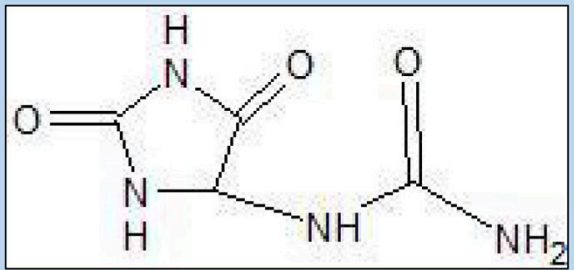

Allantoin

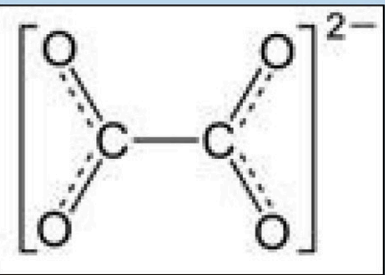

Oxalate

FIGURE 3 | Chemical structure of selected bioactive compounds from Dioscorea species with medicinal potential.

radical scavenging activity assay, and anti-lipid peroxidation test.

In the year 2002, Gao et al. (2002) observed the antitumor-promoting effect with ethanol extracts of the tubers of D. bulbifera L. using the neoplastic transformation assay of mouse epidermal JB6 cell lines. Later, Oh and Lim (2008) testified the antioxidant activity of glycoproteins isolated from D. batatas Decne. Theersin and Baker (2009) identified various phenolic compounds in D. hispida Dennst. and analyzed their antioxidant potential while Sonibare and Abegunde (2012) reported the antioxidant activity and the bioactive metabolites of Dioscorea species of Nigeria. The antitumor and antioxidant potential of $D$. bulbifera L. and D. esculenta (Lour.) Burkill have also been reported (Murugan and Mohan, 2012; Wang et al., 2012). In 2016, Zhang et al. (2016) documented the antioxidant and antimutagenic activity of the mucilage polysaccharide of D. oppositifolia L. while in the same year, Liu et al. (2016) showed the antioxidant and antitumor activities of the 


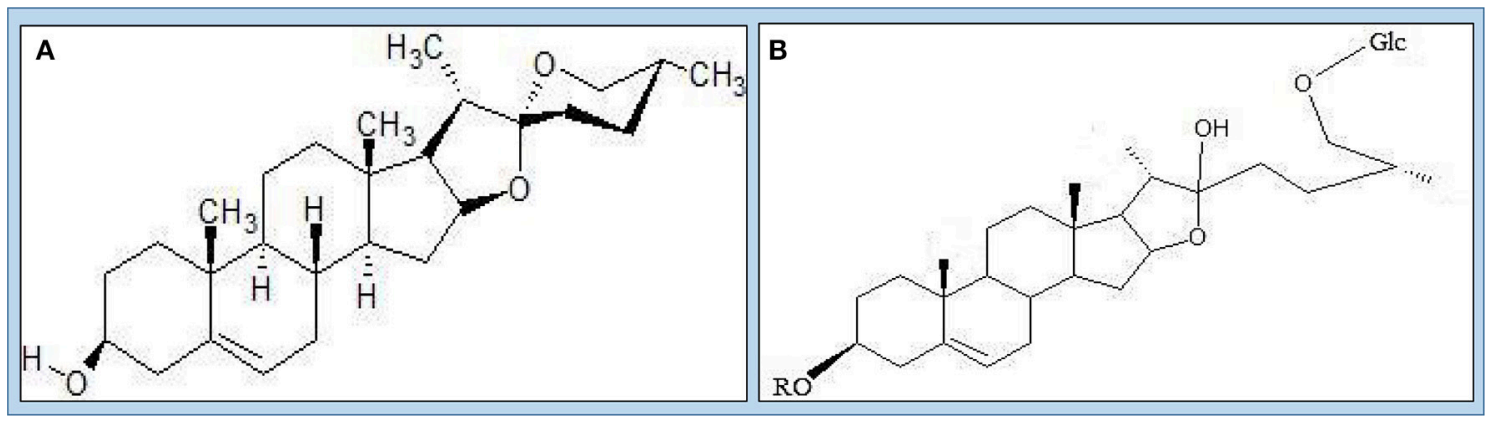

FIGURE 4 | The structure of Diosgenin, (A) Protodioscin; (B) Steroid saponins.

extracts from the flesh and peel of Chinese Yam (D. opposite Thunb.).

\section{BIOACTIVE COMPOUNDS PRESENT IN DIOSCOREA SP.}

The tuber and other parts of Dioscorea species possess different types of bioactive compounds (Table 4, Figure 3) so that its parts are used against different diseases. These bioactive compounds also reflect the indigenous therapeutic values among the many races of aboriginals of the world (Nayaboga et al., 2014). All these factors make them sound pharmacological agents and good sources for isolation and formulation of new compounds that can fight against different types of diseases. The most important component reported by Martin (1969) was diosgenin, a sapogenin used in the synthesis of steroidal drugs. Diosgenin is the primary active ingredient in Dioscorea species. It is structurally similar to cholesterol. After oral administration, it is metabolized in the liver and eliminated via the bile (Caven and Dvornik, 1979). Estrogenic and anti-inflammatory effects of diosgenin have been hypothesized due to its structural similarity to estrogen precursors. Asha and Nair (2005) reported that $D$. deltoidea Wall. ex Griseb. is the major species exploited in India for diosgenin (Figure 4) production from rhizomes.

Asha and Nair (2005) also reported the maximum diosgenin yield in $D$. pubera Blume followed by $D$. spicata, D. hispida Dennst. and D. hamiltonii Hook.f. Ozo et al. (1984) reported phenolic compounds Cyanidin-3-glucoside and the procyanidin dimmers B-1 and B-3 from D. alata L. Hou et al. (2000) reported that dioscorins present in Dioscorea species have potential to exhibit carbonic anahydrase and trypsin inhibition activities. Okunlola and Odeku (2009) reported the compression characteristics and tableting properties of starches of D. dumetorum (Kunth) Pax, D. alata L., D. oppositifolia L., and D. rotundata Poir. Avula et al. (2012) reported 20 different types of steroidal saponins from Dioscorea species using UHPLC-QTOF-MS. Franklin and Cabanillas (1966) reported the production of sapogenin in different Dioscorea species. Martin and Cabanillas (1963) reported a precursor of cortisone and related steroidal drugs from Dioscorea species.
Poornima and Ravishankar (2007) reported the bioactive compounds in D. belophylla (Prain) Voigt ex Haines as saponins, alkaloids, flavonoids, tannin, and phenols. Yoon et al. (2008) reported a bioactive compound, Allantoin, in Dioscorea rhizomes. Bhandari and Kawabata (2005) identified bitter components in Dioscorea as Furanoid norditerpenes cyanogens. Martin (1974) reported the yellow pigments of D. bulbifera $\mathrm{L}$. and that the yellow color is due to the presence of saponifiable of xanthophylls such as Lutein. The phytochemicals studies also revealed that purine derivatives, saponin, starches, and mucilage are the main constituents in Dioscorea tubers, along with allantoin, a purine derivative ( $\mathrm{Fu}$ et al., 2006). Allantoin is present as a nitrogen storage form in plants or as a product of detoxification process of ammonia in plant tissues (Fujihara and Yamaguchi, 1978). It has been also demonstrated that Dioscorea species contain higher level of allantoin than any other plants (Fu et al., 2006). Therefore, allantoin could be a good standard substance for the quality control of Dioscorea tubers because of their pharmacological importance and abundance in Diosorea species. There have been many reports to determine allantoin in biofluid with HPLC, LC-MS/MS, GC-MS (Berthemy et al., 1999; Czauderna and Kowaleczyk, 2000), and a capillary electrophoresis method for measuring allantoin content in Dioscorea tubers. D. bulbifera L. has more allantoin content than other species, which inhibits the $\alpha$-amylase and $\alpha$-glucosidase activity responsible for its antidiabetic action. It has anti-oxidant, anti-hyperglycemic, and anti-dyslipidemic activities. Methanol extract of D. oppositifolia L. has anti-ulcer activity. In 1989, Adetoun and his coworkers reported that bulbils and tubers of D. bulbifera L. contained an alkaloid, dihydrodioscorine. When crystallized in its hydrochloride form and incorporated into potato dextrose agar at a final concentration of $0.1 \%$, it was found to slow down the rate of growth of five plant pathogenic fungi: $S$. rolfsii, C. lunata, F. moniliforme, M. phaseolina, and B. theobromae.

\section{CONCLUSION AND FUTURE RESEARCH NEEDS}

Little research attention, minimal commercialization, and deficient policy frameworks are the major obstacles to harnessing 
the actual biodiversity potential of SBR. Of the phytodiversity of SBR, tubers and root crops are important so far as their uses are concerned. The wild tubers also act as a "safety net" for local people during their critical time of drought and famine. Among the tuberous wild edible medicines, Dioscorea species are quite common. They are a prime staple food substitute for the majority of rural and local people of SBR. The plant parts are quite useful in treatment of different types of diseases and disorders due the presence of a numbers of bioactive compounds. The ethnomedicinal potential of various plant species under this genus need to be validated and detailed investigations on the composition and pharmacological significance of the medicinal plants under this genus along with the standardization of the formulations used should be undertaken extensively.

The most important identified compound from Dioscorea species is diosgenin, it is presently used in the synthesis of steroidal drugs, however other potential uses of this compounds and related compounds as estrogenic, anti-inflammatory and anticancer potential need to be studied extensively. Similarly authentication of all the secondary metabolites (alkaloids, saponin, flavonoids, tannins and phenols) from this genus should be performed carefully by advanced analytical techniques to validate its quality and for conforming its biological potentials. Further studies are also required to address various issues regarding the composition of the extracts used, explicability of the preclinical experiments and lack of conversion of the preclinical results to clinical effectiveness. Attempt should also be made to conduct serious human trails and to determine the mechanism of action, bioavailability, pharmacokinetics and the

\section{REFERENCES}

Abasi, N. A., Thompson, E. D., and Onyenweaku, C. E. (2013). Measuring efficiency of yam (Dioscorea spp.) production among resource poor farmers in rural Nigeria. J. Agric. Food Sci. 1, 42-47.

Abhyankar, R. K., and Upadhyay, R. (2011). Ethno medicinal studies of tubers of Hoshangabad, M.P. bulletin of environment. Pharmacol. Life Sci. 1, 57-59.

Aderiye, B. I., Ogundana, S. K., Adesanya, S. A., and Roberts, M. F. (1996). Antifungal properties of Yam (Dioscorea alata) peel extract. Folia Microbiol. 41, 407-412. doi: 10.1007/BF02815690

Adetoun, A., and Ikotun, T. (1989). Antifungal activity of dihydrodioscorine extracted from a wild variety of Dioscorea bulbifera L. J. Basic Microbiol. 29, 265-267. doi: 10.1002/jobm.3620290504

Ahmad, F., and Uroj, A. (2008). In vitro starch digestibility characteristics of Dioscorea alata tuber. World J. Dairy Food Sci. 3, 29-33.

Ahmed, H. M. (2016). Ethnopharmacobotanical study on the medicinal plants used by herbalists in Sulaymaniyah Province, Kurdistan, Iraq. J. Ethnobiol. Ethnomed. 12, 8. doi: 10.1186/s13002-016-0081-3

Alexander, J., and Coursey, D. G. (1969). "The origins of yam cultivation," in The Domestication and Exploitation of Plants and Animals. Proceedings of a Meeting of the Research Seminar in Archaeology and Related Subjects Held at the Institute of Archaeology, London University, eds P. J. Ucko and G. H. Dimbleby (Gerald: Duckworth \& Co. Ltd.), 405-425.

APG III (Angiosperm Phylogeny Group) (2009). An update of the angiosperm phylogeny group classification for the orders and families of flowering plants: APG III. Bot. J. Linn. Soc. 161, 105-121. doi: 10.1111/j.1095-8339.2009.00996.x Araghiniknam, M., Chung, S., Nelson-White, T., Eskelson, C., and Watson, R. R. (1996). Antioxidant activity of Dioscorea and dehydroepiandrosterone (DHEA) in older humans. Life Sci. 59, 147-157. doi: 10.1016/0024-3205(96)00396-7 physiological pathways for various types of bioactive compounds for their potential applications in drug discovery and for curing various life threatening diseases. Studies should also be carried out to utilize the bioactive compounds present in these tubers for formulation of new drugs to fight against pathogenic multidrug resistant microorganisms and antimicrobial resistance. Research on these crops will open up new vistas in the study of biodiversity management for sustainable development, germplasm conservation, pharmacology and many other maiden fields of research in plant science and pharmaceutics.

\section{AUTHOR CONTRIBUTIONS}

Draft preparation: SK, JP, GD, and HS; Paper writing: SK, GD, JP; Editing: JP, HS. All authors read and approved the final manuscript.

\section{ACKNOWLEDGMENTS}

The authors are thankful to local communities of the villages Padampur, Gurguria, Kalikaparsad, and Sanuski within the SBR for describing the ethnomedicinal importance of the plant species. Authors are also thankful to Dr. R. C. Misra, National Bureau of Plant Genetic Resource for providing help. This study was supported by Korea Institute of Planning and Evaluation for Technology in Food, Agriculture, Forestry and Fisheries (IPET) through the Agricultural Research Center Project, funded by Ministry of Agriculture, Food and Rural Affairs (MAFRA) (710003-07-7-SB120).
Arinathan, V., Mohan, V. R., and Maruthupandian, A. (2009). Nutritional and antinutritional attributes of some under-utilized tubers. Trop. Subtrop. Agroecosyst. 10, 273-278.

Arnau, G., Abraham, K., Sheela, M. N., Chair, H., Sartie, A., and Asiedu, R. (2010). "Yams" in Root and Tuber Crops, Handbook of Plant Breeding, ed J. E. Bradshaw (Singapore: Springer Science Business Media, LLC), 127-148.

Arunachalam, K. D., Arun, L. B., Annamalai, S. K., and Arunachalam, A. M. (2015). Potential anticancer properties of bioactive compounds of Gymnema sylvestre and its biofunctionalized silver nanoparticles. Int. J. Nanomed. 10, $31-41$.

Asha, K. I., and Nair, G. M. (2005). Screening of Dioscorea species for diosgenin from southern western Ghats of India. Indian J. Plant Genet. Resour. 18, 227-230.

Asiedu, R., Wanyera, N. M., Nag, S. Y. C., and Nag, N. Q. (1997). Yams, CGIAR Centres. Cambridge: Cambridge University Press.

Atansov, G. A., Waltenberger, B., Wenzig, E. M. P., Linder, T., Wawrosch, C., Uhrin, P., et al. (2015). Discovery and resupply of pharmacologically active plant-derived natural products: a review. Biotechnol. Adv. 33, 1582-1614. doi: 10.1016/j.biotechadv.2015.08.001

Avula, B., Wang, Y. H., Wang, M., Ali, Z., Smillie, T. J., Zweigebbaum, J., et al. (2012). Structural characterization of steroidal saponin from Dioscorea species using UHPLC-QTOF-MS. Planta Med. 78, P1385-P1385. doi: 10.1055/s-0032-1321072

Ayensu, E. S., and Coursey, D. G. (1972). Guinea yams: the botany, ethnobotany, use and possible future of yams in West Africa. Econ. Bot. 26, 301-318. doi: 10.1007/BF02860700

Begum, A. T., and Anbazhakan, S. (2013). Evaluation of antibacterial activity of the mucilage of Dioscorea esculenta (Lour.) Burkill. Int. J. Mod. Biol. Med. 4, 140-146. 
Behera, K. K. (2006). Ethnomedicinal plants used by the tribals of Similipal Bioreserve Orissa, India: a pilot study. Ethnobot. Leaflet. 10, 149-173.

Berthemy, A., Newton, J., Wu, D., and Buhrman, D. (1999). Quantitative determination of an extremely polar compound allantoin in human urine by LC-MS/MS based on the separation on a polymeric amino column. $J$. Pharmaceut. Biomed. Anal. 19, 429-434. doi: 10.1016/S0731-7085(98)00200-3

Bhandari, M. R., and Kawabata, J. (2005). Bitterness and toxicity in wild Yam (Dioscorea spp.) tubers of Nepal plant foods. Hum. Nutr. 60, 129-135.

Bhatt, V. P., and Negi, G. C. S. (2006). Ethnomedicinal plant resources of Jaunsari tribe of Garhwal Himalaya, Uttranchal. Indian J. Trad. Knowl. 5, 331-335.

Bhogaonkar, P. Y., and Kadam, V. N. (2006). Ethnopharmacology of Banjara tribe Umarkhed taluka, district Yavatamal, Maharashtra for reproductive disorder. Indian J. Tradit. Know. 5, 336-341.

Black, R. E., Hurley, F. J., and Havery, D. C. (2007). Occurrences of 1, 4-dioxane in cosmetic raw materials and finished cosmetic products. J. AOAC Int. 84, 666-670.

Burkill, I. H. (1951). "Dioscoreaceae," in Flora of Malesiana, Vol. 4, ed C. G. G. J. Van Steenis (Djakarta: Noordhoff), 293-335.

Burkill, I. H. (1960). The organography and the evolution of Dioscoreaceae, the family of the yams. J. Linn. Soc. (Botany) 56, 319-412. doi: 10.1111/j.1095-8339.1960.tb02508.x

Caven, M. N., and Dvornik, D. (1979). Effect of diosgenin on lipid metabolism in rats. J. Lipid Res. 20, 162-174.

Chandra, S., Saklani, S., and Mishra, A. P. (2013). In vitro antimicrobial activity of Garhwal Himalaya medicinal plant Dioscorea deltoidea tuber. Int. J. Herbal Med. 1, 67-70.

Chandrasekara, A., and Kumar, T. J. (2016). Roots amd tuber crops as functional foods: a review on phytochemical constituents and their potential health benefits. Int. J. Food. Sci. 2016:3631647. doi: 10.1155/2016/3631647

Chang, S. J., Lee, Y. C., Liu, S. Y., and Chang, T. W. (2004). Chinese yam (Dioscorea alata cv. Tainung No. 2) feeding exhibited antioxidant effects in hyperhomocysteinemia rats. J. Agric. Food Chem. 52, 1720-1725. doi: $10.1021 /$ jf0345954

Choudhary, K., Singh, M., and Pillai, U. (2008). Ethno botanical survey of Rajasthan-An update. Am. Eurasian J. Bot. 1, 38-45.

Coursey, D. G. (1967). Yams: An Account of the Nature, Origins, Cultivation and Utilization of the Useful Members of the Dioscoreaceae. London: Longmans, Greens and Co. Ltd.

Cui, H., Li, T., Wang, L., Su, Y., and Xian, C. J. (2016). Dioscorea bulbifera polysaccharide and cyclophosphamide combination enhance anticervical cancer effect and attenuates immunosuppression and oxidative stress in mice. Sci. Rep. 5:19185. doi: 10.1038/srep19185

Czauderna, M., and Kowaleczyk, J. (2000). Quantification of allantoin, uric acid, xanthine and hypoxanthine in ovine urine by high-performance liquid chromatography and photodiode array detection. J. Chromatogr. B. 744, 129-138. doi: 10.1016/S0378-4347(00)00239-5

Dansi, A., Mignouna, H. D., Zoundjihe, J., Sangare, A., Asiedu, R., and Quin, F. M. (1999). Morphological diversity, cultivar groups and possible descent in the cultivated yams (Dioscorea cayenensis/Dioscorea rotundata) complex in Benin Republic. Genet. Resour. Crop Evol. 46, 371-388. doi: 10.1023/A:1008698123887

Das, S., and Das, B. P. (2008). Similipal biosphere: genesis of histrocity. Orissa Rev. Available online at: http://odisha.gov.in/e-magazine/Orissareview/2008/June2008/engpdf/June-2008-or.pdf

Das, S., Dash, S. K., and Padhy, S. N. (2003). Ethno-medicinal information from Orissa state, India, A review. J. Hum. Ecol. 14, 165-227.

Dash, N. C. (2011). Bio-cultural determinants of fertility of Mankidia: a seminomadic tribe of Odisha. Adivashi 51, 1-9.

Dong, M., Feng, X. Z., Wang, B. X., Ikejima, T., and Wu, L. J. (2004). Steroidal saponins from Dioscorea panthaica and their cytotoxic activity. Die Pharmazie Int. J. Pharma. Sci. 59, 294-296. doi: 10.1002/chin.200431154

Dutta, B. (2015). Food and medicinal values of certain species of Dioscorea with special reference to Assam. J. Pharmacog. Phytochem. 3, 15-18.

Dzialo, M., Mierziak, J., Korzun, U., Preisner, M., Szopa, J., and Kulma, A. (2016). The potential of plant phenolics in prevention and therapy of skin disorders. Int. J. Mol. Sci. 17:160. doi: 10.3390/ijms 17020160

Edison, S., Unnikrishnan, M., Vimala, B., Pillai, S. V., Sheela, M. N., Sreekumari, M. T., et al. (2006). Biodiversity of tropical tuber crops in India. Chennai: National Biodiversity Authority.
FAO (Food \& Agriculture Organization of the United Nations). (1998). The State of the World's Plant Genetic Resources for Food and Agriculture, Annual Report. Rome: FAO.

FAO (Food \& Agriculture Organization of the United Nations). (1994). The State of the Food and Agriculture, Annual Report. Rome: FAO.

Franklin, W. M., and Cabanillas, E. (1966). The F1 hybrids of some sapogeninbearing Dioscorea species. Am. J. Bot. 53, 350-358. doi: 10.2307/2439875

Fu, Y. C., Ferng, L. H., and Huang, P. Y. (2006). Quantitative analysis of allantoin and allantoic acid in yam tuber, mucilage, skin and bulbil of Dioscorea species. Food Chem. 94, 541-549. doi: 10.1016/j.foodchem.2004.12.006

Fujihara, S., and Yamaguchi, M. (1978). Effects of allopurinol [4-hydroxyprazolo (3, 4-d) pyrimidine] on the metabolism of allantoin in soybean plants. Plant Physiol. 62, 134-138. doi: 10.1104/pp.62.1.134

Gao, H., Kuroyanagli, M., Wu, L., Kawahara, N., Yasuno, T., and Nakamura, Y. (2002). Antitumor-promoting constituents from Dioscorea bulbifera L. in JB6 mouse epidermal cells. Biol. Pharm. Bull. 25, 1241-1243. doi: $10.1248 / \mathrm{bpb} .25 .1241$

Geng, Y., Zhang, Y., Ranjitkar, S., Huai, H., and Wang, Y. (2016). Traditional knowledge and its transmission of wild edibles used by the Naxi in Baidi Village, Northwest Yunnan province. J. Ethnobiol. Ethnomed. 12:10. doi: 10.1156/s13002-016-0082-2

Ghosh, S., Patil, S., Ahire, M., Kitture, R., Kale, S., Pardesi, K., et al. (2012). Synthesis of silver nanoparticles using Dioscorea bulbifera tuber extract and evaluation of its synergistic potential in combination with antimicrobial agents. Int. J. Nanomed. 7, 483-496.

Girach, R. D., Shaik, A. A., Singh, S. S., and Ahmad, M. (1999). The medicinal flora of Similiphar forests, Orissa state, India. J. Ethnopharmacol. 65, 165-172. doi: $10.1016 / \mathrm{S} 0378-8741(98) 00146-9$

Gooding, H. J. (1960). West Indian Dioscorea alata cultivars. Trop. Agric (Trinidad), 37, 11-30.

Hahn, S. K. (1995). "Yams, Dioscorea spp. (Dioscoreaceae)," in Evolution of Crops Plants, eds J. Smartt and N. W. Simmonds (London: Longman Group Limited), $112-120$.

Hahn, S. K., Osiru, D. S. O., Akoroda, M. O., and Otoo, J. A. (1987). Yam production and its future prospects. Outlook Agric. 16, 105-110.

Hailu, A. A., and Addis, G. (2016). The content and bioavailability of mineral nutrients of selected wild and traditional edible plants as affected by household preparation methods practiced by local community in Benishangul Gumaz Regional State, Ethiopia. Int. J. Food Sci. 2016:7615853. doi: $10.1155 / 2016 / 7615853$

Harijono, E. T., Sunarharum, W. B., and Hartono, M. D. (2013). Hypoglycemic effect of biscuits containing water-soluble polysaccharides from wild yam (Dioscorea hispida Dennst.) or lesser yam (Dioscorea esculenta) tubers and alginate. Int. Food Res. J. 20, 2279-2285.

Hgaza, V. K., Diby, L. N., Tie, T. B., Tschannen, A., Ake, S., Assa, A., et al. (2011). Growth and distribution of roots of Dioscorea alata L. do not respond to mineral fertiliser application. Open Plant Sci. J. 5, 14-22. doi: 10.2174/1874294701105010014

Hou, W. C., Chen, H. J., and Lin, Y. H. (2000). Dioscorins from different Dioscorea species all exhibit both carbonic anhydrase and trypsin inhibitor activities. Bot. Bull. Acad. Sin. 41, 191-196.

Hou, W. C., Hsu, F. L., and Lee, M. H. (2002). Yam (Dioscorea batatas) tuber mucilage exhibited antioxidant activities in vitro. Planta Med. 68, 1072-1976. doi: 10.1055/s-2002-36356

Hou, W. C., Lee, M. H., Chen, H. J., Liang, W. L., Han, C. H., Liu, Y. W., et al. (2001). Antioxidant activities of dioscorine, the storage protein of Yam (Dioscorea batatas Decne) tuber. J. Agric. Food Chem. 49, 4956-4960. doi: $10.1021 / \mathrm{jf} 010606 \mathrm{~m}$

Jadhav, V. D., Mahadkar, S. D., and Valvi, S. R. (2011). Documentation and ethnobotanical survey of wild edible plants from Kolhapur District. Rec. Res. Sci. Technol. 3, 58-63.

Jain, A., Katewa, S. S., Galav, P., and Nag, A. (2008). Some therapeutic uses of biodiversity among the tribal of Rajasthan. Indian J. Tradit. Know. 7 , 256-262.

Kadiri, M., Ojewumi, A. W., Aniola, T. O., and Musa, A. H. (2014). Ethnobotanical survey of plants commonly used for ceremonial activities among Yoruba tribe of south West Nigeria. Direct Res. J. Health Pharmacol. 2, $1-5$. 
Kaladhar, D. S. V. G. K., Rao, V. N., Barla, S., and Harasreeramulu, S. (2010). Comparative antimicrobial studies of Dioscorea Hamiltonii hook. f. tubers with Azadirachta indica Stem. J. Pharm. Sci. Technol. 2, 284-287.

Kamble, S. Y., Patil, S. R., Sawant, P. S., Sawant, S., Pawar, S. G., and Singh, E. A. (2010). Studies on plants used in traditional medicines by Bhilla tribe of Maharashtra. Indian J. Tradit. Know. 9, 591-598.

Keservani, R. K., Sharma, A. K., and Kesharwani, R. K. (2016). Medicinal effect of nutraceutical fruits for the cognition and brain health. Scientifica (Cairo). 2016:3109254 doi: 10.1155/2016/310925

Kumar, S., and Jena, P. K. (2014). Edible medicinal non-timber forest products from floral wealth of tribal Odisha. Sabujima 22, 41-44.

Kumar, S., Behera, S. P., and Jena, P. K. (2013a). Validation of tribal claims on Dioscorea pentaphylla L. through phytochemical screening and evaluation of antibacterial activity. Plant Sci. Res. 35, 55-61.

Kumar, S., Jena, P. K., and Tripathy, P. K. (2012). Study of wild edible plants among tribal groups of Similipal Biosphere Reserve forest, Odisha, India; with special reference to Dioscorea species. Int. J. Biol. Technol. 3, 11-19.

Kumar, S., Parida, A. K., and Jena, P. K. (2013b). Ethno-medico-biology of banaalu (Dioscorea species): a neglected tuber crops of Odisha, India. Int. J. Pharm. Life Sci. 4, 3143-3150.

Kumar, S., and Satpathy, M. K. (2011). Medicinal plants in an urban environment: plants in an urban environment; herbaceous medicinal flora from the campus of Regional Institute of Education, Bhubaneswar, Odisha. Int. J. Pharma. Life Sci. 2, 1206-1210.

Langland, K. A., and Burks, C. K. (1998). Identification and Biology of Non-native Plants in Florida's Natural Areas. Gainesville, FL: University of Florida.

Lebot, V., Malapa, R., Molisale, T., and Merchand, J. L. (2006). Physio-chemical characterisation of yam (Dioscorea alata L.) tubers from Vanuatu. Genet. Resour. Crop Evol. 53, 1199-1208. doi: 10.1007/s10722-005-2013-2

Lebot, V., Trilles, B., Noyer, J. L., and Modesto, J. (1998). Genetic relationships between Dioscorea alata L. cultivars. Genet. Resour. Crop Evol. 45, 499-509. doi: 10.1023/A:1008603303314

Lev, L. S., and Shriver, A. L. (1998). "A trend analysis of yam production, area, yield, and trade (1961-1996)," in Ligname, Plante Seculaire et Culture Davenir. Actes du Seminaire International CIRAD-INRA-ORSTOM-CORAF (Montpellier: CIRAD), 8-10.

Liu, H., Tim, K. W., Chou, G. X., Wang, J. M., Ji, L. L., and Wang, Z. T. (2011). Phenolic compounds from the rhizomes of Dioscorea bulbifera. Chem. Biodiver. 8, 2110-2116. doi: 10.1002/cbdv.201000279

Liu, Y. H., Liang, H. J., Liu, Y. W., and Hou, W. C. (2006). Comparisons of antioxidant activities of two species of yam tuber storage proteins in vitro. Bot. Stud. 47, 231-237.

Liu, Y., Li, H., Fan, Y., Man, S., Liu, Z., Gao, W., et al. (2016). Antioxidant and antitumor activities of the extracts from Chinese Yam (Dioscorea opposita Thunb.) Flesh and peel and the effective compounds. J. Food Sci. 81, H1553-H1564. doi: 10.1111/1750-3841.13322

Lu, Y. L., Chia, C. Y., Liu, Y. W., and Hou, W. (2012). Biological activities and applications of dioscorins, the major tuber storage proteins of yam. J. Tradit. Complem. Med. 2, 41-46. doi: 10.1016/S2225-4110(16)30069-4

Majumadar, K., and Datta, B. K. (2015). Vegetation types, dominant compositions, woody plant diversity and stand structure in Trishna Wildlife Sanctuary of Northeast India. J. Environ. Biol. 36, 409-418.

Maneenoon, K., Sirirugsa, P., and Sridith, K. (2008). Ethnobotany of Dioscorea L. (Dioscoreaceae), a major food plant of the Sakai tribe at Banthad Range, Peninsular, Thailand. Ethnobot. Res. Appl. 6, 385-394. doi: 10.17348/era.6.0.385-394

Martin, F. W. (1969). The species of Dioscorea containing sapogenin. Econom. Bot. 23, 373-379. doi: 10.1007/BF02860683

Martin, F. W. (1974). Tropical Yams and Their Potential: Dioscorea alata, Agriculture. Washington, DC: USAD.

Martin, F. W., and Cabanillas, E. (1963). A wild hybrid of sapogenin-bearing Dioscorea species. Bull. Torrey Bot. Club 90, 232-237. doi: 10.2307/2483231

Mbiantcha, M., Kamanyi, A., Teponno, R. B., Tapondjou, A. L., Watcho, P., and Nguelefack, T. B. (2011). Analgesic and anti-inflammatory properties of extracts from the bulbils of Dioscorea bulbifera L. var sativa (Dioscoreaceae) in mice and rats. Evid-Based Compl. Alt. 2011:912935. doi: 10.1155/2011/912935

Meena, K. L., and Yadav, B. L. (2011). Some ethnomedicinal plants used by the Garasia tribe of district Sirohi, Rajasthan. Indian J. Tradit. Know. 10, 354-357.
Mehta, P. C., and Bhatt, K. C. (2007). Traditional soaps and detergent yielding plants of Uttaranchal. Indian J. Tradit. Know. 6, 279-284.

Mignouna, H. D., and Dansi, A. (2003). Yam (Dioscorea spp) domestication by the Nago and Fon ethnic groups in Benin. Genet. Resour. Crop Evol. 50, 519-528. doi: 10.1023/A:1023990618128

Mishra, B. K. (2010). Conservation and Management effectiveness of Similipal Biosphere Reserve, Orissa, India. Indian For. 136, 1310-1326.

Mishra, N., Rout, S. D., and Panda, T. (2011). Ethno-zoological studies and medicinal values of Similipal Biosphere Reserve, Orissa, India. Afr. J. Pharm. $5,6-11$.

Mishra, R. K., Upadhyay, V. P., and Mohanty, R. C. (2008). Vegetation ecology of the Similipal Biosphere Reserve, Orissa, India. Appl. Ecol. Environ. Res. 6, 89-99. doi: 10.15666/aeer/0602_089099

Mishra, S., Swain, S., Chaudhary, S. S., and Ray, T. (2008). Wild edible tubers (Dioscorea spp.) and their contribution to the food security of tribes of Jaypore tract, Orissa, India. Plant Genet. Resour. 156, 63-67.

Misra, R. C. (1997). The Status of Rare, Endangered and Endemic Flora of Similipal Forest. Bhubaneswar: Orissa Envornmental Society.

Misra, R. C., Sahoo, H. K., Mohapatra, A. K., and Reddy, R. N. (2011). Addition to the flora of Similipal Biosphere Reserve, Odisha, India. J. Bombay Nat. Hist. Soc. 108, 69-76.

Misra, R. C., Sahoo, H. K., Pani, D. R., and Bhandari, D. C. (2013). Genetic resources of wild tuberous food plants traditionally used in Similipal Biosphere Reserve, Odisha. India. Genet. Resour. Crop Evol. 60:2033. doi: 10.1007/s10722-013-9971-6

Misra, R. K., Upadhyay, V. P., and Mohanty, R. C. (2003). Vegetation diversity of Similipal Biosphere Reserve. E-planet 1, 4-9.

Mohanta, R. K., Rout, S. D., and Sahu, H. K. (2006). Ethnomedicinal plant resources of Similipal Biosphere Reserve, Orissa, India. Zoos' Print J. 21, 2372-2374. doi: 10.11609/JoTT.ZPJ.1435.2372-4

Murugan, M., and Mohan, V. R. (2012). In-vitro antioxidant studies of Dioscorea esculenta (Lour). Burkill. Asian Pacific J. Trop. Biomed. 2, S1620-S1624. doi: 10.1016/s2221-1691(12)60464-x

Nag, A. (1999). A Study of the Contribution of Some Wild Food Plants to the Diet of Tribals of South East Rajasthan. Ph.D. thesis, Mohanlal Sukhadia University, Udaipur.

Nashriyah, M., Athiqah, M. Y. N., Amin, H. S., Norhayati, N., Azhar, A. W. M., and Khairil, M. (2011). Ethnobotany and distribution of wild edible tubers in Pulau Redang and nearby islands of Tereengganu, Malaysia. Int. J. Biol. Vert. Agric. Food Eng. 5, 110-113.

Nayaboga, E., Tripathi, J. N., Manoharan, R., and Tripathi, L. (2014). Agrobacterium-mediated genetic transformation of yam (Dioscorea rotundata): an important tool for functional study of genes and crop improvement. Front. Plant Sci. 5:463. doi: 10.3389/fpls.2014.00463

Nayak, S., Behera, S. K., and Misra, M. K. (2004). Ethno-medico botanical survey of Kalahandi District of Odisha. Indian J. Tradit. Know. 3, 72-79.

Neelima, M., Prasad, G. P., Sudarsanam, G., Pratap, G. P., and Jyothi, B. (2011). Ethnobotanical studies in Rapur forest division of Nellore district in Andhra Pradesh. Life Sci. Leaflet. 11, 333-345.

Oh, P. S., and Lim, K. T. (2008). Antioxidant activity of Dioscorea batatas Decne glycoprotein. Eur. Food Res. Technol. 226, 507-515. doi: 10.1007/s00217-007-0563-6

Okunlola, A., and Odeku, O. A. (2009). Compressional characteristics and tableting properties of starches obtained from four Dioscorea species. Farmacia $57,756-770$.

Onwueme, I. C. (1978). The Tropical Root Crops: Yams, Cassava, Sweet Potato and Cocoyams. Chichester: John Wiley and Sons Ltd.

Onwueme, I. C., and Charles, W. B. (1994). "Tropical root and tuber crops: production, prospective and future prospects," in FAO Plant Production and Protection Paper (Rome), 1-228.

Orkwor, G. C., Asiedu, R., and Ekanayaka, I. J. (1998). Food Yams: Advances in Research. Ibadan: International Institute of Tropical Agriculture/NRCRI.

Ota, A. B. (2007). Primitive tribal groups (PTGs) of Orissa: an overview. Adivasi $47,41-47$.

Ota, A. B., and Mohanty, S. C. (2008). Mankirdia. Bhubaneswar: Scheduled Castes \& Scheduled Tribes Research and Training Institute.

Ota, A. B., Mohanty, S. C., and Kodamasingh, A. (2013). Ho. Bhubaneswar: Scheduled Castes \& Scheduled Tribes Research and Training Institute. 
Ota, A. B., Mohanty, S. C., Sahoo, T., and Mohanty, B. N. (2008). Primitive Tribal Groups of Orissa. Bhubaneswar: Scheduled Castes \& Scheduled Tribes Research and Training Institute.

Ota, A. B., and Patnaik, K. (2014). Santhal. Bhubaneswar: Scheduled Castes \& Scheduled Tribes Research and Training Institute.

Ota, A. B., and Sahoo, T. (2013). The Hill Kharia. Bhubaneswar: Scheduled Castes \& Scheduled Tribes Research and Training Institute.

Ozo, O. N., Caygill, J. C., and Coursey, D. G. (1984). Phenolics of five yam (Dioscorea) species, Phytochemistry 23, 329-331.

Padal, S. B., Ramakrishna, H., and Devender, R. (2012). Ethnomedicinal studies for endemic disease by the tribes of Munchingiputtu Mandal, Visakahapatnam District, Andhra Pradesh India. Int. J. Med. Aroma. Plant. 2, 453-459.

Padmaja, G., Moorthy, S. N., Nambisan, B., Babu, L., Sundaresan, S., Sanjeev, M. S., et al. (2001). Digestibility of Starch and Protein. Thiruvananthapuram: Central Tuber Crops Research Institute.

Panda, S. K., Rout, S. D., Mishra, N., and Panda, T. (2011). Folk uses of some medicinal plants by Kol tribes of Similipal Biosphere Reserve, Orissa. India. Int. J. Biol. Technol. 2, 16-20.

Pandey, A. K., and Rout, S. D. (2003). "Ethnobiology of simlipal biosphere reserve," in XIII Annual conference of Indian Association for Angiosperm Taxonomy and International Symposium on Plant Taxonomy: Advances and Relevance (Bhagalpur: Bhagalpur University).

Pandey, A. K., Verma, S. K., Pandit, N., and Singh, L. (2000). Medicinal plants of Similipal Biosphere Reserve. J. Indian Bot. Soc. 79, 52-53.

Patil, M. V., and Patil, D. A. (2005). Ethnomedicinal practices of Nasik district, Maharashtra. Indian J. Tradit. Know. 4, 287-290.

Pedi, G. K., Dash, N. C., and Dash, J. (2013). Reproducative status of the Hill Kharias of Odisha, India. Adivashi 53, 12-26.

Pellegrini, A. F., Socolar, J. B., Elsen, P. R., and Giam, K. (2016). Trade-offs between savanna woody plant diversity and carbon storage in the Brazilian Cerrado. Glob. Chang. Biol. 22, 3373-3382. doi: 10.1111/gcb.13259

Poornima, G. N., and Ravishankar, R. V. (2007). In vitro propagation of wild yams, Dioscorea oppositifolia (Linn.) and Dioscorea pentaphylla (Linn.). Afr. J. Biotechnol. 6, 2348-2352. doi: 10.5897/AJB2007.000-2368

Prakash, G. H., and Hosetti, B. B. (2010). Investigation of Antimicrobial properties of Dioscorea pentaphylla from Western Ghats, India. Sci. World 8, 91-96. doi: 10.3126/sw.v8i8.3857

Pramila, S. S., Kumar, A., and Raghuvanshi, R. (1991). Nutrient composition of some uncommon foods consumed by Kumaon and Garhwal hill subjects. J. Food Sci. Technol. 28, 237-238.

Price, E. J., Wilkin, P., Sarasan, V., and Fraser, P. D. (2016). Metabolite profiling of Dioscorea (yam) species reveals underutilized biodiversity and renewable sources for high-value compounds. Sci. Rep. 6:29136. doi: 10.1038/srep29136

Radha, B., Singh, R. D., Tiwari, J. K., Tiwari, P., and Gairola, A. (2013). Wild edible plant resources of the Lohba Range of Kedarnath Forest Division (KFD), Garhwal Himalaya, India. Int. Res. J. Biol. Sci. 2, 65-73.

Raju, J., and Rao, C. V. (2012). Diosgenin, a Steroid Saponin Constituent of Yams and Fenugreek: Emerging Evidences for Applications in Medicine, Bioactive Compounds in Phytomedicine. In Tech. doi: 10.5772/26700. Available from: http://www.intechopen.com/books/bioactive-compounds-in-phytomedicine/ diosgenin-a-steroid-saponin-constituent-of-yams-and-fenugreek-emergingevidence-for-applications-in-

Raju, S., Thomas, P., and Rashmi, R. S. (2015). Nutritional status of tribal children in India: an overview. Int. J. Dev. Res. 5, 5276-5278.

Rajyalakshmi, P., and Geervani, P. (1994). Nutritive value of the foods cultivated and consumed by the tribals of South India. Plant Food. Hum. Nutr. 46, 53-61. doi: 10.1007/BF01088461

Reddy, C. S., Pattanaik, C., Mohapatra, A., and Biswal, A. K. (2007). Phytosociological observation on tree diversity of tropical forest of Similipal Biosphere Reserve, Orissa, India. Tawania 52, 352-359.

Reddy, D. S. (2015). Ethnobotanical studies of Dioscorea hispida Dennst. In Nallamala forest area AP, India. Rev. Res. 4, 1-4.

Rout, S. D., and Panda, S. K. (2010). Ethnomedicinal plant resources of Mayurbhanj district, Orissa. Indian J. Tradit. Know. 9, 68-72.

Rout, S. D., Panda, T., and Mishra, N. (2009). Ethnomedicinal studies on some pteridophytes of Similipal Biosphere Reserve, Orissa, India. Int. J. Med. Med. Sci. 1, 192-197.
Rout, S. D., and Thatoi, H. N. (2009). Ethnomedicinal practices of Kol tribes in Similipal Biosphere Reserve, Orissa, India. Ethnobot. Leaflet. 13, 379-387.

Roy, A., Geetha, R. V., and Lakshmi, T. (2012). Valuation of the antibacterial activity of ethanolic extract of Dioscorea villosa tubers-an in vitro study. Int. J. Pharm. Pharm. Sci. 4, 314-316.

Sahoo, L. K. (2013). Tribal Language Movement and development intervanation in Mayoubhanj District of Odisha. Adivashi 53, 97-104.

Sahu, S. C., Dhal, N. K., and Mohanty, R. C. (2010). Potential medicinal plants used by the tribal of Deogarh district, Orissa, India. Ethnol. Med. 4, 53-61.

Samanta, A. K., and Biswas, K. K. (2009). Climbing plants with special reference to their medicinal importance from Midnapore Town and its adjoining areas. J. Econom. Taxonom. Bot. 33, 180-188.

Sara, C., Lucas, L., and Keast, R. (2010). Biological activities of phenolic compounds present in virgin olive oil. Int. J. Mol. Sci. 11, 458-479. doi: $10.3390 /$ ijms 11020458

Saxena, H. O., and Brahmam, M. (1989). The Flora of Similiphar (Similipal), Orissa, with Particular Reference to the Potential Economic Plants. Bhubaneswar: Regional Research Laboratory.

Saxena, H. O., and Brahmam, M. (1995). The Flora of Orissa. Bhubaneswar: Orissa Forest Development Corporation Ltd.; Regional Research Laboratory.

Saxena, S., and Raja, A. S. M. (2014). Natural Dyes: Sources, Chemistry, Application and Sustainability Issues. Singapore: Springer International Publishing AG.

Scarcelli, N., Tostain, S., Mariac, C., Agbangla, C., Da, O., Berthaud, J., et al. (2006). Genetic nature of Yams (Dioscorea sp.) domesticated by farmers in Benin (West Africa). Genet. Resour. Crop Evol. 53, 121-130. doi: 10.1007/s10722-004-1950-5

Schulte, P. A., McKernan, L. T., Heidel, D. S., Okun, A. H., Dotson, G. S., Lentz, T. J., et al. (2013). Occupational safety and health, green chemistry, and sustainability: a review of areas of convergence. Environ. Health 12:31. doi: 10.1186/1476-069X-12-31

Schultz, G. E. (1993). Element Stewardship Abstract for Dioscorea bulbifera. The Nature Conservancy. Available online at: http://www.invasive.org/weedcd/pdfs/ tncweeds/diosbul.pdf

Seetharam, Y. N., Jyothishwaran, G., Sujeeth, H., Barad, A., Sharanabasappa, G., and Shivkumar, D. (2003). Antimicrobial activity of Dioscorea bulbifera bulbils. Indian J. Pharm. Sci. 65, 195-196.

Shajeela, P. S., Mohan, V. R., Jesudas, L. L., and Soris, P. T. (2011). Nutritional and anti-nutritional evaluation of wild Yam (Dioscorea spp.). Trop. Subtrop. Agroecosyst. 14, 723-730.

Shanthakumari, S., Mohan, V. R., and Britto, A. (2008). Nutritional evaluation and elimination of toxic principles in wild yam (Dioscorea spp.). Trop. Subtrop. Agroecosyst. 8, 313-319.

Sharma, L. N., and Bastakoti, R. (2009). Ethnobotany of Dioscorea L. with emphasis on food value in Chepang communities in Dhading District, central Nepal. Botanica Orientalis. J. Plant Sci. 6, 12-17.

Sheikh, N., Kumar, Y., Misra, A. K., and Pfoze, L. (2013). Phytochemical screening to validate the ethnobotanical importance of root tubers of Dioscorea species of Meghalaya, North East India. J. Med. Plant Stud. 1, 62-69.

Shim, W. S., and Oh, U. (2008). Histamine-induced itch \& its relationship with pain. Mol. Pain. 4, 29-32. doi: 10.1186/1744-8069-4-29

Singh, H. B., and Arora, R. K. (1978). Wild Edible Plants of India. New Delhi: ICAR Publication.

Singh, N., Pangtey, Y. P. S., Khatoon, S., and Rawat, A. K. S. (2009). Some ethnobotanical plants of Ranikhet region, Uttaranchal. J. Econ. Taxon. Bot. 33, 198-204.

Sinha, R., and Lakra, V. (2005). Wild tribal food plants of Orissa. Indian J. Tradit. Know. 4, 246-252.

Son, I. S., Kim, J. H., Sohn, H. Y., Son, K. H., Kim, J. S., and Kwon, C. S. (2007). Antioxidative and hypolipidemic effects of diosgenin, a steroidal saponin of yam (Dioscorea spp.), on high-cholesterol fed rats. Biosci. Biotechnol. Biochem. 71, 3063-3071. doi: 10.1271/bbb.70472

Son, I. S., Lee, J. S., Lee, J. Y., and Kwon, C. S. (2014). Antioxidant and antiinflammatory effects of yam (Dioscorea batatas Decne.) on azoxymethane induced colonic aberrant crypt foci in F344 rats. Prev. Nutr. Food Sci. 19, 82-88. doi: 10.3746/pnf.2014.19.2.082

Sonibare, N. A., and Abegunde, R. B. (2012). Ethnobotanical study of medicinal plants used by the Laniba village people in South Western Nigeria. Afr. J. Pharm. Pharmacol. 6, 1726-1732. 
Srivastava, R. C., and Nyishi, C. (2010). Traditional knowledge of Nyishi (Daffla) tribe of Arunachal Pradesh. Indian J. Tradit. Know. 9, 26-37.

Swain, D., and Nanda, F. (1997). Study of Plant Diversity in Newly Established Preservation Plot Inside Similipal National Park. Bhubaneswar: Orissa Environmental Society.

Swarnkar, S., and Katewa, S. S. (2008). Ethnobotanical Observation on Tuberous Plants from tribal area of Rajasthan (India). Ethnobot. Leaflet. 12, 647-666.

Tamiru, M. (2006). Assessing Diversity in yams (Dioscorea spp.) from Ethiopia Based on Morphology, AFLP Markers and Tuber Quality, and Farmers' Management of Landraces. PhD. thesis, Georg-August-University, Goettingen.

Tamiru, M., Heiko, C. B., and Brigitte, L. M. (2008). Diversity, distribution and management of Yam landraces (Dioscorea spp.) in Southern Ethiopia. Genet. Resour. Crop Evol. 55, 115-131. doi: 10.1007/s10722-007-9219-4

Terauchi, R., Terachi, T., and Tsunewaki, K. (1991). Intraspecific variation of chloroplast DNA in Dioscorea bulbifera L. Theor. Appl. Genet. 81, 461-470. doi: $10.1007 /$ BF00219435

Teron, R. (2011). Studies on Ethnobotany of Karbi-Anglong District, Assam: Transcultural Dynamism in Traditional Knowledge. PhD. thesis, Gwahati University, Assam.

Thatoi, H. N., Panda, S. K., Rath, S. K., and Dutta, S. K. (2008). Antimicrobial activity \& ethnomedicinal uses of some medicinal plants from Similipal Biosphere Reserve, Orissa. Asian J. Plant Sci. 7, 260-267. doi: 10.3923/ajps.2008.260.267

Theersin, S., and Baker, A. T. (2009). Analysis and identification of phenolic compounds in Dioscorea hispida Dennst. Asian J. Food AgroIndus. 2, 547-560.

Thongam, B., Konsam, S., and Handique, A. K. (2016). Assessment of wild leafy vegetables traditionally consumed by the ethnic communities of Manipur, Northeast India. J. Ethnobiol. Ethnomed. 12:9. doi: 10.1186/s13002-016-0080-4

Tiwari, L., and Pande, P. C. (2006). Indigenous veterinary practices of Darma Valley of Pithoragrah district, Uttranchal. Indian J. Tradit. Know. 5, 201-206.

Upadhyay, S., Sahoo, S. K., Panda, G. K., and Upadhyay, V. P. (2012). Linkages between agriculture and forest: case study from three tribal villages located in a biosphere reserve of India. Geo-Eco- Tropicol. 36, 39-48.

Van, H. P. (2016). Phenolic compounds of cereals and their antioxidant capacity. Crit. Rev. Food Sci. Nutr. 56, 25-35. doi: 10.1080/10408398.2012.708909

Wanasundera, J. P., and Ravindran, G. (1994). Nutritional assessment of Yam (Dioscorea alata) tubers. Plant Food Hum. Nutr. 46, 33-39. doi: $10.1007 / \mathrm{BF} 01088459$

Wang, J., Ji, L., Branford-White, C. J., Wang, Z. Y., Shen, K. K., Liu, H., et al. (2012). Antitumor activity of Dioscorea bulbifera L. rhizome in vivo. Fitoterapia 83, 388-394. doi: 10.1016/j.fitote.2011.12.001

Webster, J., Beck, W., and Ternai, B. (1984). Toxicity and bitterness in Australian Dioscorea bulbifera L. and Dioscorea hispida Dennst. from Thailand. J. Agric. Food Chem. 32, 1087-1090. doi: 10.1021/jf001 $25 \mathrm{a} 039$

Woo, K. W., Kwon, O. W., Kim, S. Y., Choi, S. Z., Son, M. W., Kim, K. H., et al. (2014). Phenolic derivatives from the rhizomes of dioscorea nipponica and their anti-neuroinflammatory and neuroprotective activities. J. Ethnopharmacol. 155, 1164-1170. doi: 10.1016/j.jep.2014.06.043

Xu, L., Zhou, L., Zhao, J., Li, J., Li, X., and Wang, J. (2008). Fungal endophytes from Dioscorea zingiberensis rhizomes and their antimicrobial activity. Lett. Appl. Microbiol. 46, 68-72. doi: 10.1111/j.1472-765X.2007. 02264.x

Yamani, H. A., Pang, E. C., Mantri, N., and Deighton, M. A. (2016). Antimicrobial activity of tulsi (Ocimum tenuiflorum) essential oil and their major constituents against three species of bacteria. Front. Microbiol. 7:681. doi: $10.3389 /$ fmicb. 2016.00681

Yang, M. H., Chin, Y. W., Yoon, K. D., and Kim, J. (2014). Phenolic compounds with panacreatic lipase inhibitory activity from Korean yam (Dioscorea opposite). J. Enzyme. Inhib. Med. Chem. 29, 1-6. doi: 10.3109/14756366.2012.742517

Yoganarasimhan, S. N., and Dutta, P. K. (1972). Medicinal plants of Orissa - a preliminary survey of Similiphar forests, Mayurbhanj district, Orissa. Nagarjun $15,25-27$.

Yoon, K. D., Yang, M.-H., Chin, Y. W., Park, J. H., and Kim, J. W. (2008). Determination of allantoin in Dioscorea rhizoma by high performance liquid chromotography using cyano columns. Nat. Prod. Sci. 14, 254-259.

Yu, Z. L., Liu, X. R., McCulloch, M., and Gao, J. (2004). Anticancer effects of various fractions extracted from Dioscorea bulbifera on mice bearing Hep A. China. J. Chin. Mater. Med. 29, 563-567.

Zhang, Z., Wang, X., Liu, C., and Li, J. (2016). The degradation, antioxidant and antimutagenic activity of the mucilage polysaccharide from Dioscorea opposita. Carbohydr. Polym. 150, 227-2231. doi: 10.1016/j.carbpol.2016. 05.034

Conflict of Interest Statement: The authors declare that the research was conducted in the absence of any commercial or financial relationships that could be construed as a potential conflict of interest.

Copyright (c) 2017 Kumar, Das, Shin and Patra. This is an open-access article distributed under the terms of the Creative Commons Attribution License (CC $B Y)$. The use, distribution or reproduction in other forums is permitted, provided the original author(s) or licensor are credited and that the original publication in this journal is cited, in accordance with accepted academic practice. No use, distribution or reproduction is permitted which does not comply with these terms. 